\title{
Da Etnografia à História: "Introdução" e "Conclusão" de Of Mixed Blood: Kinship and History in Peruvian Amazônia
}

\author{
Peter Gow \\ Traduçáo: $\quad$ Anna Maria de Castro Andrade, Jayne Hunger \\ Collevatti e Ugo Maia Andrade \\ Revisáo técnica: Marta Amoroso e Jessie SkLair
}

\section{Introdução}

Este trabalho é uma etnografia do povo nativo do rio Baixo Urubamba, no Peru oriental. As pessoas desta área da Amazônia peruana freqüentemente dizem ser de sangre mezclada, "de sangue misturado". Ao fazer isto, elas parecem colocar em dúvida a continuidade cultural entre elas mesmas e os ancestrais Piro, Campa e outras populaçóes indígenas da região. Tal rejeição de continuidade cultural é penetrante em seu discurso. Quando discutem a organizaçáo de suas comunidades, falam muito mais sobre a escola da aldeia e de seu título legal da terra. Suas expressóes culturais cotidianas não se encaixam naquilo que nós poderíamos designar de modelos "tradicionais" de organização comunitária, familiares aos antropólogos através de etnografias de outros povos indígenas amazônicos. De fato, eles contrastam as "vidas civilizadas" em povoados legalmente reconhecidos com escola, chamadas Comunidades Nativas, com a vida de seus ancestrais da floresta, na qual não se tinha "aldeias reais". Neste estudo apresento um relato de como as instituiçóes da escola e da Comunidad Nativa operam na organização das comunidades do povo nativo.

Este estudo também é uma etnografia num sentido mais radical. Ele busca levar a sério aquilo que os nativos do Baixo Urubamba fazem e dizem. A maioria dos antropólogos e demais pessoas, ao serem apresentados a um povo amazônico que parece rejeitar abertamente sua continuidade com o passado, e que usa uma linguagem moderna para discutir suas relaçóes sociais iriam descartá-los como "aculturados". A descrição desses povos tem sido mantida separada das várias culturas nativas amazônicas consideradas "tradicionais". Eles são vistos como vítimas da história, prejudicados pelo contato com a sociedade européia e com as sociedades nacionais. Suas culturas são consideradas sem coerência própria, uma vez que elas sofreram mudanças históricas que os distanciam da genuína cultura tradicional anterior ao contato com os estrangeiros. Se nós seguirmos esta abordagem das culturas amazônicas, deveremos olhar para as políticas educacionais e a reforma da terra do estado peruano para entender por que os nativos do Baixo Urubamba falam sobre a escola e a Comunidad Nativa, e não sobre a cultura dos povos nativos. Igualmente, a reivindicação dos nativos de serem "de sangue misturado" os exclui da categoria antropológica de culturas nativas amazônicas "puras" e nos isenta da necessidade de analisar sua cultura, o que eles dizem e fazem.

Mas se ouvirmos o que os nativos dizem e procuramos entendê-los, chegaremos a uma conclusão radicalmente diferente. Ao evocar a escola e a Comunidad Nativa como base para a ação comunitária, eles evocam, simultaneamente, por contraste, as vidas de seus ancestrais, que viveram na floresta. Especialmente, 
eles evocam as narrativas de escravidão e opressão sofridas por seus ancestrais e por alguns parentes mais velhos. Os ancestrais foram escravizados pelos brancos e seus descendentes viveram e trabalharam em sistema de débito ("barracão") nas haciendas. Os mais velhos viveram essa experiência de violência e as "aldeias reais" de hoje foram vitórias obtidas frente à oposição dos patróes brancos. Cada referência à escola e à Comunidad Nativa ressoa contra a narrativa de violência e opressão. Para os nativos, "ser civilizado" náo é oposto a uma cultura idílica "tradicional" que vem se perdendo, mas sim se opóe à ignorância e ao desamparo dos antigos ancestrais moradores da floresta. Ser "civilizado" é ser autônomo, viver em aldeias de acordo com os valores dos próprios nativos, ao invés de viver dos caprichosos desejos de um patrão.

Quais são esses valores? Falando com os nativos, logo se apreende que eles querem "viver bem", como eles mesmos dizem. Eles querem comer "comida de verdade", que são os produtos de suas hortas, da pesca do rio e caça da floresta. Querem morar com seus parentes, que lembrarão de sua fome e irão alimentá-los. Querem morar em comunidades pacíficas e felizes, rodeadas por parentes cuidadosos, livres da opressão dos patróes. Seus valores são os valores do parentesco. Como mostro neste estudo, o idioma do parentesco permeia toda a sua linguagem, a escola e a Comunidad Nativa são idiomas de parentesco, quando vistas de dentro da cultura nativa. Por causa disto, as pessoas nativas do Baixo Urubamba apresentam um paradoxo para os antropólogos. É o uso que elas fazem da escola e do título legal da terra que as revela como "aculturadas", e diferentes das culturas nativas amazônicas "tradicionais". Mas esta mesma linguagem codifica a centralidade do parentesco em suas relaçóes sociais, revelando-os idênticos a esses outros povos amazônicos. Procuro mostrar que este parado- xo apresenta-se somente porque os etnógrafos insistiram em conceber povos "aculturados" em termos históricos e culturas "tradicionais" em termos a-históricos. O paradoxo é dissolvido quando se abandona a oposição "aculturado"/ "tradicional" como definidora de tipos particulares de culturas.

A abordagem adotada nesta etnografia coloca a história no centro da análise, mas o presente estudo não é uma análise histórica das pessoas nativas do Baixo Urubamba. Ao contrário, ela lida com a história de dentro da cultura dos povos nativos. A constante evocação do passado nas vidas dos nativos deve ser referida a seus próprios valores. Para as pessoas nativas, a história é o parentesco. A história não é experimentada como uma força que vem de fora para corromper uma estrutura atemporal de deveres e obrigaçóes de parentesco. As relações de parentesco são criadas e dissolvidas no tempo histórico que confere significados e influências para os nativos ao serem estruturadas pelas relaçóes de parentesco. Este é um fato de extrema importância, pois desafia a visão dominante dos povos nativos amazônicos como historicamente impotentes. Este estudo procura mostrar que os povos nativos amazônicos são agentes históricos ativos e que para entender sua agência precisamos compreender os significados culturais de suas açóes, tanto agora quanto no passado.

\section{As comunidades nativas do Baixo Urubamba}

Meu interesse em estudar os Piro do Baixo Urubamba veio de um breve contato que tive com os Campa das áreas do Gran Pajonal, Tambo e Ene em 1978. Estas pessoas, apesar de uma longa história de contato com estrangeiros ${ }^{1}$, correspondiam à imagem que eu tinha

1. Veja Varese, 1973b, Bodley 1970 e Lehnertz 1972 sobre a história dos Campa. 
de uma cultura nativa amazônica "tradicional": eram largamente monolíngues em Campa, sua cultura material era basicamente de manufatura local e tinham poucos contatos diretos com pessoas náo-Campa. Ao planejar estender meu trabalho de campo para o doutorado, decidi estudar um povo nativo amazônico que estivesse em contato mais próximo com povo não-nativo. Optei pelos Piro do Baixo Urubamba que moram perto dos Campa, mas que estáo em contato muito mais intensivo com os brancos. Interessava-me especialmente a organizaçáo social das aldeias piro e como esta organização estava relacionada à sua integraçáo no mercado de trabalho madeireiro. Mais especificamente, eu estava interessado em como os Piro mantinham sua identidade étnica face a esse contato, com respeito particularmente aos altos níveis de casamentos interétnicos que foram registrados entre eles pela missionária Matteson (1955: 25) do Summer Institute of Linguistics e pelo missionário dominicano Alvarez (1957). Esses autores, ambos com longa experiência entre os Piro, produziram vários trabalhos que, apesar de indicarem o envolvimento intensivo dos Piro com seus vizinhos nativos e brancos, subentenderam que essas pessoas formavam um grupo étnico discreto na área do Baixo Urubamba. Outros autores deram a mesma impressão sobre os Piro (i.e. Loeffler e Baer 1974, Chirif e Mora 1977, Ribeiro e Wise 1978). Além disso, uma considerável literatura histórica traçou o percurso dos Piro através dos séculos desde seu primeiro contato com os europeus no século XVI.

A despeito de não alimentar ilusóes de que veria uma antiga cultura amazônica nativa, mesmo assim minha primeira experiência direta com as pessoas nativas do Baixo Urubamba foi um pouco chocante. Conheci as comunidades de Huau, Santa Clara e Nueva Itália em 1980, quando o céu baixo da estação chuvosa encobrindo as águas lodosas e volumosas do
Urubamba compunha uma cena deprimente. Todos vestiam roupas de estilo ocidental, muitas casas tinham telhado de zinco, mobília de estilo europeu e a maioria das ferramentas usadas eram de manufatura náo local. Essas comunidades não tinham, de imediato, nada do charme exótico das aldeias Campa que conhecera anteriormente. A comunicação com essas pessoas deveria ter sido mais fácil do que foi com os Campa do Ene ou do Pajonal, pois a maioria das pessoas do Baixo Urubamba são perfeitamente fluentes em espanhol. Muitos não falam outra língua. Mas talvez devido a esta aparente facilidade, estava ciente de que muitas pessoas náo gostavam da minha presença entre elas e mesmo suspeitavam de minhas intenções de estar por lá.

Essas foram, obviamente, simples impressôes iniciais. Mas não tinha a sensação, conforme se passavam as semanas e meses, de que esta "aculturaçáo" fosse um aspecto superficial dessas comunidades, sob o qual a cultura piro funcionava como no passado. $\mathrm{Na}$ verdade, os Piro mostravam ser extremamente evasivos sobre sua cultura. Por mais que fosse óbvio que muitas pessoas ao meu redor falassem Piro e fossem identificadas como Piro tanto por elas mesmas quanto pelos outros, eu não me sentia seguro de estar realmente entre os Piro. Muitas pessoas nas três comunidades ao redor da boca do rio Huau não são Piro, em nenhum sentido. Muitos são Campa, outros são imigrantes da parte mais baixa do Ucayali ou da cidade de Pucallpa. Algumas dessas pessoas falam Piro, mas muitas não. Até mesmo entre aquelas que se dizem Piro há quem não possa falar essa língua e o mesmo é verdade entre os Campa, com respeito à língua Campa. De maneira mais confusa, o fato de uma pessoa ser Piro ou náo parecia depender do meu interlocutor: a mesma pessoa poderia ser identificada por alguém como Piro, por outro como Campa e por um terceiro como moza gente, um termo que pode 
ser traduzido como "mestiço". Além disso, individualmente as pessoas poderiam trocar sua auto-identificação dependendo da ocasião. Uma mulher se afirmava como sendo Piro para alguns visitantes Campa, enquanto que uma semana mais tarde ela anunciava para outros visitantes: "Yo Campa!", "Sou Campa!".

Essa complexidade na identificação estava ligada a um sistema lingüístico que era completamente inesperado. Com exceção das crianças e de alguns homens de Ucayali, as pessoas que moravam nas comunidades que eu conhecia melhor eram multilingües. A maioria dos adultos falava espanhol fluente e qualquer uma das duas línguas, Piro ou Campa; alguns adultos falavam as três, e algumas pessoas mais velhas falavam Piro e Campa, mas não espanhol. Freqüentemente, as conversas cotidianas envolviam duas línguas diferentes, às vezes três: um locutor falava Piro, enquanto seu interlocutor respondia em espanhol, e um terceiro interviria na conversa em Campa. A maioria das crianças falava somente o espanhol. Entretanto, seus pais, e especialmente suas máes, freqüentemente se dirigiam a elas em Piro ou Campa. Eu não pude entender bem como as crianças aprenderam o espanhol, uma vez que esse padrão era tão bem desenvolvido em crianças pré-escolares quanto nas mais velhas. Quando, em desespero, eu perguntava às pessoas nativas sobre este problema, elas pareciam não achar nada particularmente estranho nisso, apontando simplesmente que seus filhos nunca tentaram falar a língua nativa dos pais. Durante os primeiros meses de trabalho de campo, busquei achar uma comunidade mais "Piro" para estudar, e, com este fim, viajei rio acima para Sepahua. Entretanto, até onde posso afirmar, todas as comunidades Piro eram caracterizadas pelo mesmo nível de heterogeneidade.

Apesar da complexidade das questóes de identidade e língua, as pessoas das comunidades de Huau, Santa Clara e Nueva Itália falavam so- bre elas mesmas e sobre seus vizinhos de forma extremamente consistente. Todas realçavam, ao falarem comigo, que eram gente civilizada, e diferenciavam a si mesmas dos Campa do Gran Pajonal e do Amahuaca e Yaminahua, que habitavam a parte oriental do Baixo Urubamba, que eram, por sua vez, gente de monte, "gente da floresta", ou indios bravos. As pessoas me diziam que seus ancestrais também eram "gente da floresta", mas que elas mesmas se tornaram "civilizadas". Os comentários depreciativos sobre a "gente da floresta" eram uma constante característica da vida cotidiana: as crianças mal comportadas eram repreendidas com exclamaçôes de "Yaminahua!" ou "Amahuaca!".

A princípio supus que essa constante referência a eles mesmos como "civilizados" e aos seus vizinhos como "gente da floresta" não civilizada era resultado da nossa interação. Reconhecendome como um estrangeiro poderoso, os nativos estavam motivados, eu imaginei, a enfatizar nossa civilidade comum, em oposição aos "índios bravos". Suspeitei que esta constante fala sobre o tema de ser civilizado era um tipo de racismo e auto-aversão, que essas pessoas odiavam o "povo da floresta” porque saberiam que elas também eram "pessoas da floresta", desprezadas pelos brancos. Ao perderem sua própria cultura, esses nativos tiveram que se defrontar com os aspectos mais brutais e sem sentido da cultura dos brancos. Neste momento, eu estava particularmente influenciado pela análise de Cardoso de Oliveira sobre a situação problemática do caboclo do Alto Solimóes: o caboclo é o índio que não se vê como um Tukuna, mas como um ser inferior através dos olhos do "Mestre", o homem branco (1972: 83). Isso pareceu extremamente apropriado às pessoas do Baixo Urubamba.

Quando tentei coletar dados sobre a organização social dessas comunidades nativas, encontrei a mesma situaçáo. Longe de apelar ao parentesco, matrimônio ou chefia como princípio de organização social, os nativos apelavam, 
constantemente, para duas, instituiçóes: a legalmente reconhecida Comunidad Nativa e a escola. A Comunidad Nativa, baseada na lei de reforma de terras ocupadas no Peru amazônico promulgada no início de 1970, parecia um princípio organizacional peculiarmente inadequado para esse povo. No tempo do meu trabalho de campo, Santa Clara era somente uma Comunidad Nativa registrada há cinco anos, enquanto que as comunidades vizinhas haviam se registrado um ano antes de Santa Clara. Por que esta instituição nova deveria dominar o relato da organizaçáo social dos nativos? Como uma complicação a se somar ao problema da identificaçáo, o povo local habitualmente se auto-identificava nas conversas como gente nativa, uma designação que suprimia as diferenças tribais, mas que enfatizava a diferenciação entre eles e os brancos. Quando perguntava aos informantes o significado do termo yine - que a literatura invariavelmente traduz como a autodenominação dos Piro $^{2}$-, me diziam enfaticamente que o termo significava "povo nativo", e não "Piro". Como uma autodenominação, gente nativa era uma estranha denominaçáo, uma vez que só pode ter entrado no uso local com o registro das comunidades nativas ${ }^{3}$. Até mesmo o nome que este povo usava para se autodescrever era inautêntico, emprestado do Estado peruano.

Com relação às escolas no Baixo Urubamba, sendo instituiçóes mais velhas, que começaram no início dos anos de 1950, podendo, em conseqüência, ser atribuída a elas uma maior "tradição", parecia ainda assim menos apropriado que funcionassem enquanto princípio

2. Veja Matteson (1965: 397); Alvarez (1970: 36); Chirif e Mora (1977: 170); d'Ans (1982: 262); Ribeiro e Wise (1978: 157).

3. Os termos gente nativa ou los nativos foram introduzidos pela agência de reforma agrária SINAMOS (Sistema Nacional de Apoyo a la Movilización Social) para substituir termos como indio ou indigena, ambos considerados pejorativos para funcionarem como palavra de ordem de um sistema de reforma agrária progressista. organizador da estrutura da comunidade. A escola parecia personificar tudo o que ameaçava a cultura nativa amazônica. Em Santa Clara, o currículo escolar excluía quase toda referência à cultura tradicional, e a instrução era exclusivamente em espanhol. Perguntava-me se os nativos do Baixo Urubamba tinham sido tão traumatizados em suas experiências com a sociedade peruana nacional e com a civilização ocidental em geral, a ponto da frágil linha da cultura tradicional haver se quebrado, forçando-os a fazer o melhor que podiam com os detritos deixados para trás desta experiência histórica cruel.

Mas se essa explicação parecia vigorosa, deixava muita coisa sem explicação. Para começo, os nativos que cheguei a conhecer náo pareciam confusos ou profundamente perturbados e, muito menos, infelizes. Ao contrário, pareciam muito convictos e tinham um considerável senso de humor. Tinham, em certas áreas, um apreço muito alto por si mesmos. Isto era particularmente perceptível com respeito à comida. Inicialmente, as pessoas me pediam desculpas por serem incapazes de me prover de comidas a que supunham que eu estaria acostumado. Quando ficou claro que eu estava bem feliz em comer banana da terra cozida, peixe do rio e cerveja de mandioca, eles se tornavam efusivos em seus elogios, pois ficava óbvio que eu gostava de comida verdadeira. Durante todo meu período no Baixo Urubamba, toda vez que eu visitei uma casa estranha, a anfitriã perguntava, nervosa, aos meus companheiros, se eu "sabia como beber cerveja de mandioca". Meus companheiros anunciavam alto: "El sabe tomar!" ("ele sabe como tomar!") e eu poderia ser incluído na apresentação das grandes tigelas de cerveja. Freqüentemente, depois de uma refeição particularmente boa de algum tipo de caça altamente apetitosa, as pessoas me perguntavam: "Como você irá voltar para seu país? Você não pode comer essas coisas lá". 
A falta de interesse na cultura "tradicional" que havia me deprimido tanto em minha primeira estadia no Baixo Urubamba se revelou com o tempo algo mais complexo. Em aldeias como Santa Clara, ninguém vestia o cushma, roupa de algodão trançado em estilo antigo, preferindo roupas compradas em lojas, mas a comida comprada em loja era considerada com desprezo, como um último recurso quando tudo mais falhara. Todos queriam comer a caça e a pesca da floresta e do rio, banana da terra e cerveja de mandioca. E enquanto as pessoas me diziam que agora elas eram civilizadas, e moravam em comunidades legalmente registradas que giravam em torno da rotina diária da escola, elas eram veementes nas críticas da vida das cidades como Pucallpa, onde as pessoas eram más e a comida não era de graça. Onde inicialmente ouvira nada além de desprezo pelos “índios selvagens”, tornei-me, posteriormente, mais sensível às convicçóes dos nativos de que eles viviam de uma maneira que era, do ponto de vista moral, superior às vidas das pessoas da cidade, aquelas mesmas que eles pareciam se empenhar arduamente por imitar. Comecei a entender que meu próprio interesse em "índios selvagens" ou na cultura dos ancestrais, abertamente expresso por mim quando cheguei, havia preocupado os nativos. Havia falado com eles como um missionário ou um chefe branco, romanceando as vidas do "povo da floresta". Os nativos são perfeitamente cônscios de que este romance vai ao encontro de manipulação e exploração do "povo da floresta” ignorante. Antes de nos conhecermos melhor, os nativos temiam que eu fosse um poderoso estrangeiro. Ao morar com eles aprendi aos poucos a ouvir com cuidado o que diziam e a agir em relação a eles com respeito, valor altamente valorizado em suas relaçóes interpessoais. Ao fazer isso, me disseram mais tarde, havia me tornado "como família", confiável, respeitável e memorável.
Essa experiência pessoal se refletiu em minha posição analítica. Tornou-se claro que as vidas dos nativos do Baixo Urubamba náo poderiam ser entendidas em termos de uma oposição entre uma cultura "tradicional", que estava sendo perdida, e uma cultura "moderna" que tomara seu lugar. As coisas eram muito mais complexas. Por que o povo indicava a Comunidad Nativa e a escola, ambas instituiçóes externas, para explicar porque as pessoas moravam juntas em aldeias onde a atividade mais importante era um ciclo incessante de distribuiçáo de carne de caça e cerveja de mandioca? Que lógica ligava a afirmação dos nativos de que eles eram um "povo civilizado" à sua óbvia preferência por comida tirada da floresta? Um indício para uma solução possível repousa em uma história que me contaram tantas vezes que ela quase equivale ao mito de origem de toda a área do Baixo Urubamba. Era-me dito, com respeito a alguma pessoa em particular, que o pai dele ou dela era de afuera, "de fora" (de fora do Baixo Urubamba ou mesmo da Amazônia), enquanto que a mãe dele ou dela era uma paisanita, "uma mulher da tribo", ou seja, uma mulher Piro ou Campa. Tal afirmação se referia especialmente àquelas pessoas conhecidas como gente blanca, "gente branca", os madeireiros locais ou os donos de loja no centro administrativo de Atalaya. Ocasionalmente, me foi contado sobre um patrão local particular ou um chefe, que ele era "de fora", mas sua mulher era Campa. A imagem é potente para o povo do Baixo Urubamba: um homem estrangeiro casa com uma mulher local e permanece para criar as crianças na área. É também uma imagem verdadeira da maioria dos próprios Piro, assim como muitos Campa, que são produto de várias gerações desses casamentos interétnicos. Constantemente me era dito pelo povo nativo, "Somos gente mezclada, somos de sangue mezcla$d a$ ", "nós somos um povo misturado, nós somos de sangue misturado". A heterogeneidade dos habitantes dessas comunidades nativas, seu 
multilingüismo e sua afirmação aparentemente contraditória de valores opostos estavam, assim, intimamente conectados a sua auto-identificação como "povo misturado".

\section{Culturas nativas Amazônicas: etnogra- fia e história}

Face à situação etnográfica esboçada acima procurei, em campo e nas análises posteriores dos dados, entender as comunidades nativas do Baixo Urubamba nos termos dos estudos prévios dos povos nativos amazônicos. Os nativos do Baixo Urubamba são um exemplo clássico de um povo Amazônico "aculturado", foi inicialmente para estudos de aculturação e mudança social que me voltei. A despeito da variedade de abordagens existente na literatura, achei todas insatisfatórias para a análise do Baixo Urubamba: todas falharam quando procuraram relacionar história e etnografia e, em particular, o significado da história para os povos nativos amazônicos.

Acumulamos hoje várias tendências importantes nas análises de povos "aculturados" na Amazônia. Uma das primeiras abordagens é aquela que eu irei chamar de estudos de aculturação, representada pelos trabalhos de Wagley e Galvão, Baldus e Murphy ${ }^{4}$. O foco nesses estudos é o processo pelo qual uma cultura amazônica nativa muda por assimilação das características culturais de outra sociedade com a qual ela veio a ter contato historicamente. Neles, o contato entre culturas é o canal ao longo do qual as características culturais circulam e é de pouco interesse nele mesmo. $\mathrm{O}$ tema central para o projeto dos estudos de aculturação é o conceito de "assimilação": após um período suficientemente prolongado de contato e mu-

4. Os exemplos são Wagley e Galvão (1949), sobre os Tenetehara, Galvão (1959), sobre os povos do Rio Negro, Baldus (1964), sobre os Tapirapé, e Murphy (1960), sobre os Mundurukú. dança cultural, a cultura particular da sociedade nativa amazônica se torna idêntica às suas vizinhas, e, em conseqüência, seus membros se tornam assimilados à sociedade envolvente. A imagem dominante da história amazônica apresentada pelos estudos de aculturação é a de povos amazônicos nativos perdendo suas culturas distintas e se tornando assimilados à massa não-indígena de camponeses rurais, um prognóstico encontrado no estudo de Wagley e Galvão sobre os Tenetehara do Maranhão (1949). Um tema similar é encontrado no trabalho de Bodley sobre os Campa (1970), no qual ele mapeia a transformação socioeconômica dos Campa de uma cultura tradicional, através do sistema de patrón, para uma comunidade moderna baseada no cristianismo e nas relaçóes de mercado 5 .

Esta abordagem talvez se encaixe nos nativos do Baixo Urubamba muito bem, mas é vencida pela complexidade da estrutura cultural da área. Quem está aculturando quem no Baixo Urubamba? Ao passo que existe um grande acúmulo de documentação histórica dos povos do Baixo Urubamba desde a metade do século XVI, é extremamente difícil decidir se qualquer prática particular do povo nativo contemporâneo deriva ou não do contato histórico com outros povos, ou, ao menos, quando tal prática foi adotada. Um exemplo simples disto é o uso do espanhol. Obviamente, os povos PréColombianos do Baixo Urubamba não falavam espanhol. Mas quando o espanhol começou a ser usado pelo povo nativo do Baixo Urubamba? Poder-se-ia supor que o espanhol começou

5. Os trabalhos tanto de Murphy (1960) e Bodley (1970) são, de alguma forma, diferentes dos estudos de aculturação mais antigos, pois eles enfatizam a mudança econômica ao invés de mudanças culturais abstratas. Entretanto, eles permanecem no interior da mesma tradição, dado que eles vêem a mudança econômica como a força motora da mudança das culturas tribais para culturas não-tribais. 
a ser usado seguindo o contato intensivo com os chefes da borracha que falavam espanhol por volta do final do século, ou mesmo como um resultado da educação bilíngüe nos anos de 1950. Mas viajantes do Baixo Urubamba de meados do século XIX notaram que ao menos alguns dos Piro podiam falar espanhol, e considerando os laços comerciais antigos tanto nos Andes quanto no resto da Amazônia, o padrão era provavelmente mais velho ainda. Além disso, o espanhol falado no Baixo Urubamba é um dialeto distinto, comum para a bacia do Ucayali, e contém muitos itens léxicos de Quéchua e outras origens indígenas. Portanto, a qual cultura ele deveria ser referido? É claro que não ao espanhol europeu, nem ao espanhol da costa do Peru andino. Problemas similares de origens culturais nascem em relação a muitos aspectos culturais do povo nativo do Baixo Urubamba.

As dificuldades que encontrei com uma abordagem de aculturação para o povo nativo do Baixo Urubamba fizeram a análise alternativa de Ribeiro e Cardoso de Oliveira, no Brasil, e Varese, no Peru, parecer mais atrativa ${ }^{6}$. Em desacordo direto com os estudos de aculturação, esses autores, e muitos outros nesta tradição, argumentam que o contato não é um canal inerte, mas uma relaçáo concreta de dominação. $\mathrm{O}$ foco, desta maneira, muda das diferenças abstratas entre culturas para uma única diferença crucial: o desejo por dominação e controle, que é característica da "civilização" ou "sociedade nacional". Para esses autores, as sociedades nacionais são dominadoras, imperialistas e expansionistas, enquanto que sociedades indígenas são insulares, igualitárias e estáticas. Os trabalhos de Ribeiro, Cardoso de Oliveira e Varese estão, claramente, de acordo com a divisão de Lévi-Strauss entre sociedades "frias" e "quentes" (1977: 29). O trabalho de

6. Veja Ribeiro (1970), sobre todo o Brasil, Cardoso de Oliveira (1972), sobre os Tukuna, e Varese (1973 e 1972) sobre os Campa.
Ribeiro, em particular, está preocupado em traçar a seqüência evolucionista que acompanha a colonização das sociedades indígenas pela sociedade nacional, indo de povos náo contatados até o indio genérico. Essencialmente, essa seqüência, que Ribeiro chama de "transfiguração étnica" consiste na remoção violenta de toda especificidade cultural dos povos indígenas, até que eles permaneçam como "entidades étnicas" destituídas de toda especificidade cultural (1970: 446).

O problema em aplicar este modelo em particular no Baixo Urubamba é o de ser praticamente impossível decidir quem pertence à sociedade nacional e quem pertence à sociedade tribal. Por exemplo, vários dos homens de uma comunidade como Santa Clara não iriam identificar a eles mesmos com nenhum grupo tribal: esses homens, tão importantes e ativos nos negócios da comunidade, deveriam ser considerados como membros da sociedade nacional? Similarmente, muitas mulheres Piro, Campa e Amahuaca moram com seus maridos não-nativos fora das comunidades nativas: essas mulheres deveriam ser consideradas membros da sociedade tribal? Ainda mais confuso é o fato de as muitas pessoas brancas locais, incluindo o ex-prefeito da Atalaya, serem atribuídas relações de parentesco com o povo nativo. Essas pessoas são membros da sociedade nacional ou tribal? Tais problemas fazem o tipo de análise proposta por Ribeiro extremamente problemática, pois estas análises repousam na oposiçáo entre sociedade nacional e tribal.

Os mesmos problemas se aplicam à análise da situação interétnica feita por Cardoso de Oliveira. Em seu estudo dos Tukuna do Alto Solimóes, Cardoso de Oliveira argumenta que há uma contradição entre a sociedade nacional e a sociedade tribal, e que cada uma é caracterizada por um "campo semântico" distinto que inviabiliza a comunicação entre elas (1972: 31-2). No Baixo Urubamba, existem certas 
diferenças práticas muito importantes entre os brancos e os nativos, mas duvido que qualquer comunicação entre eles seja impossível. Se as pessoas habitualmente tecem comentários pejorativos a respeito do comportamento umas das outras, esses comentários revelam não ignorância ou confusão, mas, ao contrário, um conhecimento profundo dos valores dos outros. Por exemplo, o povo branco local freqüentemente me dizia como o povo nativo era sujo. Isto não era um mau entendido dos valores diferentes dos nativos sobre higiene, mas um insulto bem deliberado. Os brancos sabem quanto os nativos são sensíveis a esta acusação. Igualmente, os nativos acusam os brancos de serem sovinas com a comida, e de cobrar dos visitantes por hospedagem. Isto também é um insulto intencional, atacando a convicçáo dos brancos de que eles são hospitaleiros. Mas geralmente os nativos e os brancos revelaram, em conversas comigo, um extenso entendimento das motivaçóes e valores uns dos outros. Realmente, valores tais como limpeza e generosidade com a comida são gerais para qualquer um do Baixo Urubamba: os brancos e os nativos diferem somente em eleger suas urgências como fontes de ação. Isto não é um problema de tradução, mas sim de poder. Os conflitos entre os brancos e os nativos no Baixo Urubamba derivam não de incompreensão mútua, mas do fato de que eles entendem um ao outro muito bem.

Outra abordagem, relacionada aos estudos de conflito interétnico e, mais incidentalmente, aos estudos de aculturação, é encontrada nos estudos de etnicidade. Esta abordagem é representada pelo trabalho de Whitten sobre os $\mathrm{Ca}$ nelos Quíchua (1976 e 1985), por Scazzachio sobre os Lamista Quéchua (1979) e por Stocks sobre os Cocamilla (1976 e 1984). Nestes estudos, apesar de uma certa dependência de análises históricas, o foco é, primordialmente, a construção dos valores de diferentes grupos étnicos e a relação entre eles. Implicitamente, estes estudos questionam a noção de assimilação, por revelar como culturas amazônicas nativas podem mudar com o passar do tempo enquanto mantêm uma diferenciação dos vizinhos não nativos. Entretanto, tentar usar este enquadramento para as análises do Baixo Urubamba levou-os aos mesmos tipos de problemas que emergiram do trabalho de Ribeiro e de Oliveira: como alguém define a identidade étnica no Baixo Urubamba? A manutenção das fronteiras (veja Barth, 1969) dificilmente poderia ser a característica mais importante dessas comunidades cheias de "povos misturados".

Obviamente, seria difícil analisar o sistema social do Baixo Urubamba como a interação de grupos étnicos discretos, dado a multiplicidade de identidades. Mas, igualmente, é questionável se tal abordagem faria avançar nosso entendimento deste sistema, pois é a multiplicidade de identidades, e como estas funcionam como um sistema, que deveria constituir o interesse primordial. Whitten (1976 e 1985) e Taylor (1981) notaram uma situação muito similar a essa do Baixo Urubamba entre os Canelos Quíchua, Shuar e Achuar do Equador, mas suspeito que o uso da etnicidade como um enquadramento metodológico obscureceu, mais do que elucidou o problema. Blu, em seu estudo dos Lumbee dos EUA, comenta:

Idealmente, o termo etnicidade deveria ser completamente deixado de lado como um termo intercultural analíticamente útil. Ao invés, deveria ser restrito àquilo que faz de melhor, a saber, uma importante forma de diferenciaçáo social nos Estados Unidos. Mas sendo que isso é tão provável quanto a nossa suspensão do uso do termo raça exceto em um senso genético estrito, alguma outra solução terá que ser encontrada. Certamente, nenhum uso dos termos "étnico" e "etnicidade" deve ocorrer sem extensiva e detalhada descrição da situação a qual se refere em termos tanto sociológicos quanto culturais (1980: 227). 
Este é, precisamente, o problema no Baixo Urubamba: o que, exatamente, significam termos como "Piro", "Campa", "mestizo", ou "branco" para o povo local? É fato que estes termos se referem a algum tipo de diferença, mas não são claras essas diferenças. Não temos nenhuma razão para pressupor qualquer conteúdo particular para esses termos, nem para supor que esses modos de classificação são idênticos as nossas próprias visóes de fora do que seriam "tribos" amazônicas ou "grupos étnicos". O mesmo se aplica ao trabalho de Whitten sobre os Canelos Quíchua. Na sua impressionante etnografia dos Canelos as noçóes de cultura e identidade e a multiplicidade de aspectos e densidade simbólica que envolvem encaixamse incomodamente no enquadramento da etnicidade (1985: 107-63).

O problema central em todos os modos de análise discutidos acima é a prioridade analítica dada à história. A cultura da sociedade nativa amazônica em estudo é entendida em termos de uma modificação de uma situação anterior, base original ou cultura "tradicional", ou em termos de contato interétnico gerido pela história. Igualmente, a categoria social ao redor da qual a análise é construída é a das fronteiras geradas pelo contato histórico de diferentes culturas ou sociedades, de modo que a distinção categórica considerada importante é aquela que se estabelece entre os portadores da cultura tradicional e os portadores da cultura estrangeira, entre os membros da sociedade tribal e os membros da sociedade nacional ou entre grupos étnicos que existiram antes desse contato. Para todos esses modelos de análise, o foco está na transformaçáo da cultura ou sociedade "tradicional" sob o impacto do contato com uma cultura ou sociedade de fora. Esse processo é concebido como história.

Em O Pensamento Selvagem, Lévi-Strauss argumenta que não pode haver história final porque todas as histórias devem ser referidas a um sujeito particular para quem esta história tem significado (1966: 257). A etnografia, neste sentido, é a descoberta desses significados dos sujeitos particulares. Desta perspectiva, nós podemos ver que os estudos discutidos acima freqüentemente falham enquanto etnografias. Pouca atenção é dada nesses estudos à explicação de por que e como o povo contemporâneo fala e age. Realmente, em contraste marcado com etnografias de povo "tradicionais", os escritores muitas vezes descartam ou criticam informaçôes particulares dos informantes como se estas não fossem dados etnográficos a serem explicados. Assim, Cardoso de Oliveira descreve o relato de seu informante Tukuna sobre a propriedade da terra como "falsa consciência" porque é fora daquilo que Oliveira supunha como o sistema de posse de terra "tradicional" dos Tukuna (1972: 94). Similarmente, Ribeiro descarta o relato de Las Casas do uso do termo caboclo no rio Tapajós como "percepçóes locais que confundem posiçóes socioculturais distintas" (1970: 376). Certamente, o dever do etnógrafo é analisar os sistemas de posse de terra e classificação social, e não fazer preleções aos informantes sobre qual seria a sua verdadeira cultura.

A etnografia de Whitten sobre os Canelos Quichua levanta uma questão fundamental sobre a forma pela qual a etnografia de povos amazônicos "aculturados" tem sido escrita. Assim como os nativos do Baixo Urubamba, estes povos têm sido descartados como um povo "aculturado" de pouco interesse adicional. Mas o trabalho de Whitten revelou uma cultura de complexidade notável, particularmente na dicotomia alli runa / sacha runa ("pessoa cristâ" / "pessoa da floresta”) (1976). Similarmente, a análise de Taylor sobre as reaçóes dos Achuar à influência missionária mostra a importância de endereçar o entendimento dos povos nativos amazônicos para instituiçóes como a escola (1981). A força dessas análises vem de sua 
preocupação com os significados culturais dos povos nativos amazônicos, mesmo quando esses significados se referem a aspectos aparentemente externos de suas vidas. Nesses estudos, e em outros mais recentes, como de Fernández (1986), Muratorio (1987) e Faulhaber (1987), a história cessa de ser de fora das culturas nativas amazônicas, infringindo sobre eles, e toma seu lugar de direito dentro delas.

Assim, uma solução para os problemas analíticos de entender as comunidades nativas do Baixo Urubamba, e a que sigo aqui, é explorar os discursos locais de identidade, cultura e história. Ao invés de tentar identificar uma cultura "tradicional" em documentos históricos, poder-se-ia indagar aos nossos informantes como era do ponto de vista deles, a cultura dos "povos antigos". Similarmente, ao invés de tentar identificar cada pessoa no Baixo Urubamba como portador de uma cultura particular, como membro de uma sociedade tribal ou nacional particular, ou um grupo étnico particular, podemos explorar as categorias salientes de identidade usadas pelos próprios povos locais. Além disso, ao invés de tentar enquadrar a história do Baixo Urubamba no esquema ou dos estudos de aculturação ou de contato, podemos indagar ao povo local quais processos e eventos eles consideram significativos em sua história.

Ao explorar porque a Comunidad Nativa, a escola e o idioma de "povo misturado" são tão importantes para os nativos do Baixo Urubamba na definiçãa de suas comunidades, não focalizo a história dessas instituiçôes e idiomas, mas sim como estas se relacionam com as outras instituiçóes e idiomas usados pelo povo nativo. Assim, não oponho a importância contemporânea da comunidade nativa ou da escola para os nativos à organizaçáo "tradicional" da aldeia, mas prefiro explorar a maneira que os nativos opóem a Comunidad Nativa e a escola a outros idiomas, como "viver na floresta" ou ser "escravos dos patrōes”. O método é, primordialmen- te, etnográfico, ao invés de histórico. No lugar de apelar para o que nós conhecemos sobre a recente organizaçáo social das comunidades nativas do Baixo Urubamba para elucidar sua organização contemporânea, foco aquilo que o povo nativo afirma sobre sua organizaçáo comunitária e como isto se relaciona com o que disseram ou fizeram em outros aspectos de suas vidas.

Essa metodologia levanta um sério problema. Não disponho de nenhuma boa evidência dos idiomas da organizaçáo comunitária que os nativos usaram dez anos antes do meu trabalho de campo, muito menos de um século atrás. Não busco, assim, relacionar os dados que recolhi com os relatos históricos do Baixo Urubamba. A questão é identificar como o povo local usa seus idiomas e tal investigação não deveria ser prejudicada neste momento por tentativas de encaixar essas práticas a um discurso externo sobre história. Isto é particularmente importante já que os povos nativos dão considerável ênfase a sua própria narrativa histórica local para explicar a natureza de sua cultura. Estive assim preocupado em elucidar o que esta narrativa significa para os nativos e não se ela se amolda em uma reconstrução da história local vinda de fora, feita por meio da análise de evidências documentadas. Como Strathern afirmou em sua análise da noção de aldeia na Inglaterra rural, "quando os moradores de Elmdon dizem, então, que fulano é uma verdadeira pessoa de aldeia, ou um recém chegado declara que as verdadeiras famílias de Elmdon têm estado lá por gerações, nós não devemos perguntar se é verdade, mas porque isso importa” (1981: 17). O problema aqui é de análise histórica: ao passo que seria ridículo argumentar que a importância da Comunidad Nativa ou da escola para os nativos do Baixo Urubamba é tradicional, uma simples afirmação de que não é não nos ajuda a entendê-la. Diferentemente do que se passa com 
certas partes da Amazônia, é possível construir esta história do Baixo Urubamba com alguma profundidade, mas a riqueza comparativa da documentação histórica é ilusória num certo sentido. Tanto missionários quanto viajantes nos proveram de breves relatos sobre os povos nativos da área ao longo dos quatro últimos séculos, mas em muitas áreas vitais a documentação é precária e enigmática. Esses escritores tiveram relativamente pouco interesse ou experiência com os nativos, pois eles náo eram antropólogos. Eu não questiono que estudos históricos são importantes, mas eu questiono a prioridade analítica da história. Lévi-Strauss (1981: 627) argumentou que novas estruturas são transformaçóes das estruturas antecedentes, e, assim, a história não tem começo. A própria noção de um único momento, quando a mudança histórica começa, é uma ilusão. O passado do Baixo Urubamba está além do nosso alcance, e sua prioridade analítica é duvidosa. Assim, a explicação histórica deve ser deixada de lado por enquanto, e o foco deve se dirigir para o que os antropólogos fazem de melhor: etnografia.

Seguindo Lévi-Strauss, minha preocupação aqui é com o significado da história para os nativos do Baixo Urubamba, ao invés de qualquer história a respeito deles. Quando eu discutia a história da área com meus informantes, ficava óbvio que os nativos têm um interesse forte pelo passado. Eles narram este passado de uma maneira particular, é o relato de como este povo se tornou "gente civilizada", em oposição aos ancestrais "povos da floresta". Além disso, as narrativas históricas dos nativos envolvem uma constante referência ao parentesco e à posição de quem fala em relação ao passado. Tal estilo de narrativa histórica é relacionado ao parentesco, considerado central na constituição da cultura dos nativos, e, conseqüentemente, central para a presente análise. Por este mesmo motivo julgo ser importante evitar o uso das narrativas históricas dos nativos para desenvolver uma história “objetiva” da área. Não porque acredite que os relatos dos nativos sobre o passado não sejam verdadeiros, longe disso, mas por considerar que elas formam parte dos dados etnográficos a serem explorados ${ }^{7}$.

$\mathrm{O}$ método adotado para este estudo foi o de permitir que os dados etnográficos me levassem o mais longe possível, guiado por uma postura teórica: há um tipo de ordem no discurso simbólico usado pelo povo do Baixo Urubamba. E desde que é melhor trabalhar do conhecido para o desconhecido, sigo a direção dos trabalhos recentes em etnografias de outros povos nativos amazônicos e exploro as áreas do simbolismo temporal e espacial, economia, parentesco e matrimônio, ciclo de vida, padrão de residência, chefia e xamanismo. Esses temas têm sido explorados em um grande número de etnografias recentes da Amazônia, no corpo principal deste trabalho disponho o relato do povo nativo do Baixo Urubamba no contexto desses estudos. Assim como a maioria dessas etnografias, o método seguido aqui é funcionalista, no sentido de uma procura por coerência entre diferentes aspectos da organização social dos nativos do Baixo Urubamba em termos de sua co-presença, no mesmo tempo e espaço. A diferença mais importante é que não faço nenhuma especulação sobre a profundidade do tempo, ou natureza "tradicional" das práticas discutidas aqui ${ }^{8}$. $\mathrm{O}$ método central do trabalho de campo foi simplesmente observar o que as pessoas faziam e o que elas diziam para mim e para as outras. Reuni o quanto pude de informação geral sobre o sistema social local e

7. Cf. discussão de tais histórias indígenas em Morphy e Morphy (1984) e Carrier (1987).

8. A qualidade "como se fosse" da presente análise é fortemente "como se fosse" (cf. Leach 1954: 7). Nem reivindico a duração histórica das práticas contemporâneas, e nem que a cultura dos povos nativos forma um sistema fechado. 
sua história, mas o foco foi sempre o de observar como os próprios povos locais falavam e agiam.

\section{Conclusão: o Baixo Urubamba na perspectiva amazônica}

Segundo Joana Overing, na base das diferentes estruturas sociais das terras baixas sulamericanas está uma única filosofia social: "o universo existe, a vida existe, a sociedade existe apenas à medida que há contato e mistura adequada entre coisas diferentes" (Overing Kaplan 1981: 161). Seu argumento é persuasivo e ressoa nas culturas amazônicas, com suas profundas preocupaçóes com a dualidade, a reciprocidade, a segurança e o perigo da alteridade. As culturas amazônicas tornaram-se variaçóes sobre este tema essencial. Overing Kaplan (1981) e Viveiros de Castro (1986) têm defendido a unidade essencial de todas as culturas indígenas amazônicas, substituindo o evolucionismo e o particularismo das áreas culturais presentes em análises comparativas anteriores. Viveiros de Castro, em particular, destacou que essa unidade é topológica (1986: 276): náo existe elemento básico ausente ou presente em cada cultura, mas, antes, todas essas culturas são variantes de uma única estrutura de relações. Nenhuma cultura "possui" essa estrutura básica, sendo que a estrutura existe nas relaçóes transformacionais entre todas elas. Overing e Viveiros de Castro têm mostrado como esta estrutura básica explica as similaridades e diferenças entre as culturas Jê-Bororo do Brasil Central, os povos Tukano do Noroeste amazônico e as culturas Caribe-Piaroa das Guianas.

A filosofia social das pessoas nativas do Baixo Urubamba fornece uma solução para o enigma da diferença - perigosa, porém criativa, e da igualdade - segura, porém estéril, enigma este táo radical quanto aquele encontrado nos povos das Guianas ou do Brasil Central analisa- dos por Overing Kaplan (1981). Segundo esta autora, a residência endogâmica dos Piaroa e os complexos sistemas de metade dos Jê-Bororo obscurecem a identidade e a diferença entre as categorias sociais. Eu poderia sustentar que as pessoas no Baixo Urubamba fazem algo similar, mas de uma forma talvez mais radical. No momento elas têm oposto as identidades pessoais dos contemporâneos às diferenças radicais e perigosas entre os "tipos de gente" de geraçóes passadas. Cada pessoa no Baixo Urubamba é produto da unidade da extrema diferença nas geraçóes anteriores. Categorias sociais puras, os "tipos de gente" existem no Baixo Urubamba, mas elas não existem na forma de indivíduos. Essas categorias puras existem como identidades pessoais totais apenas no passado, em países distantes e na experiência dos que tomavam a datura. Como os pólos opostos do presente e do parentesco, o passado e a experiência da datura definem todas as pessoas vivas no Baixo Urubamba como "pessoas misturadas". O "aqui e agora” do Baixo Urubamba é composto por "pessoas misturadas" vivas, em oposição às categorias puras do passado, da datura e dos lugares distantes.

A caracterizaçáo de Overing da filosofia sócio-cosmológica dos índios das terras baixas sul-americanas ajusta-se bem às pessoas nativas do Baixo Urubamba. Para que as pessoas pudessem viver nas aldeias verdadeiras como pessoas civilizadas, elas experimentaram um longo e complexo processo de mistura apropriada da diferença, lindamente expresso no idioma das "pessoas misturadas". Para que este processo continue, novas diferenças devem ser encontradas e incorporadas. Isto corrobora o progressismo das pessoas nativas do Baixo Urubamba e sua fascinação pelos "estrangeiros brancos" e os “índios selvagens”. É somente por meio desse processo que as pessoas conseguem imaginar a continuação da vida. Encontramos novamente diante do mesmo paradoxo da cultura nativa 
do Baixo Urubamba, pois é na sua "falta de tradição" que vislumbramos sua unidade com as culturas "tradicionais". Mas as pessoas nativas do Baixo Urubamba são muito diferentes dos Piaroa, dos Bororo, dos Tukano e dos Araweté. A cultura nativa do Baixo Urubamba pode ser vista, assim, como uma transformação dessas outras culturas, sendo, portanto, essas diferenças de natureza topológica.

A comunidade nativa do Baixo Urubamba, se comparada às aldeias unitárias dessas outras sociedades, é uma comunidade voltada para o exterior. As pessoas nativas não podem imaginar uma comunidade auto-suficiente, pois todas as comunidades são construídas sem a domesticação da diferença radical. A comunidade nativa, lugar do parentesco, imobiliza em seu interior as forças que são mais destrutivas ao parentesco. O conhecimento dos civilizados, que freqüentemente ameaça escravizar as pessoas (dispersando seus filhos e destruindo a co-residência) é controlado na Comunidad Nativa e na escola, enquanto o conhecimento dos espíritos maléficos do rio e sobre a floresta, que freqüentemente ameaça matar as pessoas, é controlado nas atividades do xamá. Essas formas perigosas de conhecimento são, assim, utilizadas para defender a energia do corpo e a memória, os processos construtivos centrais da comunidade nativa. Igualmente, os perigos potenciais dessas formas de conhecimento são controlados através dos processos que constroem o parentesco.

Tanto os Piaroa quanto as pessoas nativas do Baixo Urubamba vêem a comunidade como um conjunto heterogêneo de "tipos de gente", embora os "tipos de gente" sejam apenas realidade post-mortem para os Piaroa (Kaplan 1975: 203-205). Ambas as sociedades defendem que comunidades são formadas por consangüíneos e acentuam que estes deveriam viver juntos. Mas as pessoas nativas do Baixo Urubamba invertem as políticas matrimoniais dos Piaroa discutidas por Overing (Kaplan, 1975: 146182, 186-194). Onde os Piaroa apagam os perigos do matrimônio e da afinidade mediante o "casar perto", as pessoas nativas do Baixo Urubamba apagam os perigos do não-parentesco entre os diferentes "tipos de gente" utilizando a produção do matrimônio a fim de ramificar largamente laços de consangüinização entre as novas geraçóes. Mais comumente, as comunidades nativas do Baixo Urubamba demonstram marcar oposição àquelas sociedades guianenses analisadas por Rivière (1984). Nada poderia estar mais distante da comunidade nativa do Baixo Urubamba que o desejo guianense por grupos locais sem afinidade ou diferença $(i b .:$ 70-71), embora isto não oculte o desejo, comum às duas áreas, de comunidades onde todos sejam considerados consangüíneos. A diferença é que as pessoas do Baixo Urubamba vêem sua comunidade como algo a ser criado, enquanto as sociedades guianenses vêem a sua como algo a ser preservado.

As comunidades nativas do Baixo Urubamba, construídas sobre um modelo de intercasamentos entre diferentes "tipos de gente", apresentam grande semelhança com os povos Tukano e Arawak do Noroeste amazônico'. Em cada caso, a aldeia isolada não possui realidade separada de seu espaço em um sistema mais amplo de diferentes "tipos de gente". O contraste mais marcante é que, enquanto os povos do Noroeste amazônico freqüentemente recriam a diferença em relação a cada nova geração através dos rituais masculinos de iniciação, as pessoas do Baixo Urubamba vêem cada nova geração como diferença gradativamente misturada. A iniciação masculina no Noroeste amazônico, atuando através de uma elevada oposição entre homens e mulheres e suas capacidades reprodutivas, coloca em contato

9. Cf. S. Hugh-Jones (1979), C. Hugh-Jones (1979), Arhem (1981) e Bidou (1972 e 1977) sobre os povos Tukano, e Hill (1984) sobre um povo Arawak. 
cada nova geraçáo masculina com a ancestralidade e, dessa forma, "favorece" a acumulação de geraçóes (S. Hugh-Jones 1979: 248-251; C. Hugh-Jones 1979: 107-168; J. Hill 1984: 535-539). Onde, no Noroeste Amazônico, a aliança simétrica entre diferentes tipos de gente é produzida no interior do casamento, no Baixo Urubamba o idioma do "sangue misturado" produz tal diferença no âmago do parentesco. Diferentemente do Noroeste Amazônico, onde a diferença primordial de tipos de gente é incessantemente renovada, no Baixo Urubamba o sistema está constantemente se expandindo por meio da mistura continuada e da busca por novas diferenças.

Pode parecer inadequado comparar os "tipos de gente" do Baixo Urubamba aos grupos de descendência unilinear do Noroeste Amazônico. Na tradição antropológica estruturalfuncionalista os "tipos de gente" desempenham funçóes sociais radicalmente distintas em cada caso e são, portanto, incomparáveis. Entretanto, Overing (Overing Kaplan 1981) tem sugerindo uma ponte ao comparar em suas análises as relaçôes entre os clâs Bororo, os grupos exogâmicos Vaupés e os clãs dos tempos míticos dos Piaroa. A similaridade entre os clãs míticos Piaroa e os "tipos de gente" do Baixo Urubamba não precisa ser trabalhada aqui, mas a associação dos "tipos de gente" do Baixo Urubamba com o território, com a linguagem e conhecimento e com as origens no passado profundo, os coloca muito próximos aos grupos exogâmicos Vaupés. Entretanto, o mais marcante e eloqüente é a similaridade da experiência da comunidade do Baixo Urubamba com a datura e a atual organização social dos Bororo (Lévi-Strauss 1970: 37-43; Crocker 1979). Em ambos os casos, a comunidade é formada por categorias sociais mutuamente exclusivas, habitando casas separadas em uma única aldeia.

É tentador argumentar aqui que as pessoas nativas do Baixo Urubamba são forçadas a "alucinar" o que os Bororo alcançam na prática, seguindo uma das famosas comparaçóes de Lévi-Strauss (1973) sobre a pintura facial kadiwéu e a sociedade bororo. A experiência $\mathrm{da}$ datura presenteia as pessoas nativas do Baixo Urubamba com uma imagem fantasiosa de suas próprias aldeias. Entretanto, não podemos atribuir prioridade analítica da "verdadeira" estrutura da sociedade bororo sobre a "verdadeira" estrutura das comunidades nativas do Baixo Urubamba ${ }^{10}$. Como argumentaram Overing Kaplan (1981) e Viveiros de Castro (1986), a sociedade e a cosmologia não podem ser facilmente separadas no estudo das culturas nativas amazônicas. Quando muito, nas análises comparativas, podemos questionar porque alguém compreende uma solução particular qualquer como a organização da aldeia, enquanto outro a compreende na experiência alucinógena, conduzindo uma solução bastante distinta na prática diária. Além disso, a simples existência de tamanha variedade de organizaçóes comunitárias diferentes na Amazônia sugere que todas são soluçôes perfeitamente viáveis para o problema de se fazer aldeias.

Se buscamos resposta para o fato de que visões específicas da comunidade são realizadas de formas particulares pelos diferentes povos nativos da Amazônia, devemos abandonar

10. Os Kayapó, como descritos por Lea (1986), elaboram uma instância intermediária entre a aldeia Bororo e a comunidade nativa do Baixo Urubamba. Como os clâs e as linhagens Bororo, as "casas" kayapó (para utilizar uma expressão de Lea) são associadas a nomes particulares e rituais de opulência. Mas, como as comunidades nativas do Baixo Urubamba, em qualquer tempo esses nomes e objetos de rituais de opulência são distribuídos em uma aldeia kayapó através das atuais casas. A complexidade do nome e riqueza transmitidos entre os Kayapó tem pouco em comum com a "cristalina" estrutura da sociedade Bororo, mas muito em comum com a maneira pela qual as pessoas nativas do Baixo Urubamba marcam a produção do parentesco em suas narrativas sobre a história. 
qualquer esforço de encontrar uma estrutura "básica" da qual outros sistemas são elaboraçóes. Ao invés disso, no terreno da história, o projeto comparativo deve seguir as pistas sugeridas pelo sistema de transformaçóes topológicas das organizaçóes sociais nativas amazônicas existentes. Melhor que perguntarmos por que as sociedades guianenses náo podem criar elaboradas instituições comunais, como os Jê (Rivière 1984: 108-109), ou por que os Jê-Bororo não podem formar relações intercomunais elaboradas como os povos do Noroeste Amazônico (Turner 1979: 175), podemos perguntar por que os povos das Guianas são bons em criar pequenas aldeias densamente entrelaçadas ou por que os Jê-Bororo são bons em fazer grandes aldeias separadas entre si.

Essas formas de organização comunitária são, claramente, adaptaçóes a alguma coisa. Essa "alguma coisa" pode ser somente a própria história. Não devemos saber, a priori, o que essa história é para os guianenses, os Jê-Bororo ou os povos do Noroeste Amazônico, mas podemos começar a formular as possibilidades através de uma análise de seus resultados ${ }^{11}$. Essa é uma das mais importantes implicaçóes deste estudo sobre as pessoas nativas do Baixo Urubamba: ao rejeitar as soluçóes históricas superficiais para as particularidades da organização social dessas pessoas, ele revela a história como o problema central nas análises de todas as culturas nativas amazônicas.

A organização comunitária das pessoas nativas do Baixo Urubamba é uma transformação incomum de outros sistemas nativos amazônicos, mas não é única. O sistema de parentesco do Baixo Urubamba carrega algumas grandes similaridades com aquele dos Canelos Quíchua descrito por Whitten (1976 e 1985). As comunidades canelos são desenvolvidas pelos xamãs

11. Veja Lévi-Strauss (1963) sobre o falso "arcaísmo" dos Nambikwara e Price (1987) para uma interessante solução histórica para esse problema.
(Whitten 1976: 141-161) e guiadas através de um complexo simbolismo espacial que opóe o caserío na borda do território comunitário e em contato com o Estado às casas dispersas no centro do território e, portanto, mais próximas à floresta (ib.: 1985). No Baixo Urubamba é a escola que serve como o foco da comunidade, não o xamã. Mas as diferenças não são tão dramáticas, pois no Baixo Urubamba o conhecimento representado pela escola e o conhecimento xamânico estáo intimamente ligados enquanto modelos. Nos Canelos, o conhecimento xamânico é proveniente de espíritos ancestrais da floresta (Whitten 1976: 148-153); as pessoas manipulam a identidade caserio/floresta (alli runalsacha runa) na prática social. No Baixo Urubamba, tanto o conhecimento xamanístico quanto o da escola vêm de regióes à jusante e esses poderes externos estáo relacionados aos poderes da floresta na criação histórica da Comunidad Nativa. Em ambos os casos, há um complexo entrelaçamento entre o "civilizado" e a "floresta" na produção de um termo central, a comunidade composta por parentes.

Os sistemas sociais dos Canelos Quíchua e das pessoas nativas do Baixo Urubamba têm uma característica adicional em comum, pois ambos funcionam através da multiplicidade de identidades pessoais. Em ambos os sistemas uma pessoa pode estar, simultaneamente, em duas categorias formalmente opostas. Isto se comprova, sem dúvida, pela maneira como ambos os sistemas funcionam em contínuo contato com outros sistemas sociais que são organizados de forma diferente. Os Canelos Quíchua intercasam em peso com os Shuar e os Achuar (Whitten 1976 e 1985; Taylor 1981), enquanto as pessoas nativas do Baixo Urubamba intercasam com os Tambo, Campa do Gran Pajonal e com Machiguenga do Alto Urubamba (cf. Casevitz 1977). Whitten e Taylor sustentam que as culturas Canelos Quíchua e Shuar / Achuar, mesmo muito dife- 
rentes, são variantes transformacionais (Whitten, 1976; Taylor, 1981: 666-667). O mesmo provavelmente é verdadeiro para a situação do Baixo Urubamba ${ }^{12}$. Esta sugere que um entendimento das culturas nativas amazônicas como sistemas de transformaçóes topológicas é mais que um jogo estruturalista desempenhado por antropólogos e é a prática social concreta de muitos povos nativos amazônicos. Se as pessoas nativas amazônicas podem "alucinar" outros modos possíveis de organizaçáo, podem igualmente se ocupar deles na prática. Este assunto novamente levanta a questão da história.

\section{Da etnografia à história}

O foco principal deste estudo foi a etnografia das pessoas nativas do Baixo Urubamba, e a história foi abordada aqui como um assunto etnográfico, por meio da narrativa histórica das pessoas nativas. Entretanto, muitos problemas históricos emergem dessa etnografia das pessoas nativas. Pretendo aqui discutir como a etnografia do Baixo Urubamba se volta a uma reinterpretação da história amazônica, escrita agora com o pleno reconhecimento da agência histórica do povo nativo da Amazônia.

Mostrei anteriormente como a organização social das comunidades do Baixo Urubamba pode ser interpretada como uma transformação topológica de outras sociedades indígenas amazônicas. Apenas superficialmente as pessoas

12. Em comunicação pessoal, Graham Townsley (que estudou os Yaminahua) e Soren Hvalkof (que estudou os Campa do Pajonal) discordaram radicalmente de minhas análises da situação do Baixo Urubamba, baseados na idéia de que estes dois povos constituem unidades culturais evidentes. Contudo, suspeito que estávamos situados em planos diferentes. AnneChristine Taylor contou-me que os Achuar subestimam sua identidade Quíchua, enquanto os Canelos enfatizam sua identidade Achuar. Em tais sistemas complexos, a multiplicidade de identidades não precisa ser acentuada por todos os povos envolvidos. nativas do Baixo Urubamba são "aculturadas", pois o intenso e prolongado contato com a civilização e com o homem branco, sem mencionar os casamentos interétnicos, têm apagado muito dos elementos diacríticos da cultura indígena amazônica. Que a organização social dessas pessoas possa ser comparável àquela das culturas indígenas amazônicas "tradicionais" é ao mesmo tempo inesperado e improvável. Porque seria assim?

A razão é que, em parte, os antropólogos têm raramente experimentado este tipo de comparação, e nesses termos. Como já discuti, os povos "tradicionais" são habitualmente analisados de maneira completamente diferente dos povos "aculturados". A ênfase nos estudos do primeiro tipo está na coerência cultural e integração, quanto que no segundo tipo de estudo a ênfase reside na incoerência cultural e desintegração que se operou por meio da agência histórica. Dada esta divisão na abordagem, não é surpresa que uma comparação mais profunda entre povos "tradicionais" e "aculturados" mostrese inviável: as premissas desses dois estilos de etnografia são bastante distintas ${ }^{13}$. A possibilidade de comparar as pessoas nativas do Baixo Urubamba com culturas "tradicionais" como os Piaroa, Vaupés Tukano, Machinguenga, reflete a natureza de meu projeto etnográfico. Seguindo o estilo dessas etnografias de povos "tradicionais", procurei por coerência e integração nas vidas das pessoas nativas, não incoerência e desintegração. Em lugar de atribuir parte da prática das pessoas nativas à cultura tradicional e o resto à falsa consciência ou às percepçóes

13. Nota-se que muitos estudos clássicos de povos "aculturados" baseiam-se em uma comparação entre um segmento "tradicional" do povo estudado e outro "aculturado", como os estudos de Cardoso de Oliveira (1972), Bodley (1970) e Murphy (1960). Tais estudos prestam insuficiente atenção aos problemas analíticos que emergem da presença sincrônica dos dois estágios de "história". 
distorcidas, procurei pela coerência interna entre diferentes campos de práticas.

Com esta escolha por um estilo particular de descrição etnográfica e análise, não estou sugerindo que as pessoas nativas do Baixo Urubamba pertençam a uma cultura indígena tradicional. Ao invés disso, proponho desafiar a visão da história que sustenta a divisão entre povos "tradicionais" e "aculturados". Se é possível descrever e analisar um povo "aculturado" em termos de coerência e integração cultural, então devemos questionar se a história realmente rompe a coerência das culturas amazônicas nativas. Pelo mesmo motivo, devemos nos certificar se a relativa ausência de história nas etnografias dos povos tradicionais representa algo mais que uma convenção estilística. Se a diferença entre os dois estilos de etnografia se baseia em uma falsa visão da história amazônica, então a nova abordagem para a etnografia que venho utilizando aqui conduzirá a uma nova e melhor abordagem para esta história.

A natureza enigmática da história me foi fortemente revelada pela profundidade temporal da documentação da história sobre os Piro e Campa. Enquanto trabalhava no Baixo Urubamba, soube através de leituras, que os Piro haviam matado o padre jesuíta Enrique Richter em 1695, pondo fim às esperanças dos jesuítas de controlar a regiáo do Ucayale/Urubamba e supus que várias daquelas pessoas ao meu redor eram descendentes de seus assassinos. Descobrir que a morte de Richter não tinha nenhum interesse para meus informantes não foi uma grande surpresa. Perturbava-me, no entanto, o contrate entre meu conhecimento dessa história e minha ignorância sobre minha própria história. Não sabia o que meus ancestrais na Escócia haviam feito três séculos atrás e menos ainda como eram. O que significava saber mais sobre a história do Baixo Urubamba que a da minha própria terra? O que há de tão especial na "história"?
As pessoas nativas poderiam discutir o último século de mudanças radicais na sociedade local em termos de parentesco, as relações práticas de suas vidas cotidianas. Não poderia fazer o mesmo porque meu conhecimento sobre meu próprio passado estava dividido entre um pequeno número de fragmentos acerca de parentes mais antigos e um conhecimento razoavelmente coerente sobre a "história mundial" aprendida nos livros. Esta última história era puramente abstrata para mim e eu tinha pouca noção de que eu ou alguém que conhecia era agente ativo desse cenário de narrativas. Estou certo de que esta é a experiência histórica da maioria dos "povos históricos", para adaptar a respeitável formulação de Wolf (1982). O conhecimento dos povos nativos sobre o passado não é simplesmente impressionante; é também uma forma potente de consciência histórica. Quando meus informantes estruturavam uma narrativa histórica sobre o passado com a frase: "Mi mamá me contó que ..." (Minha mãe me contou que ...), era eu, e não eles, que reagia à aparente insuficiência da história doméstica contada face à história mundial. Para gente nativa, uma narrativa obtém seu poder de veracidade precisamente de tais relaçôes de parentesco próximo. Essa é outra dimensão para minha análise da história como parentesco para as pessoas nativas do Baixo Urubamba. História é a narrativa da criação do parentesco contemporâneo $e$ a fonte das respostas das pessoas nativas às novas situaçóes.

Se tomarmos seriamente a identificação que essas pessoas fazem da história com o parentesco, podemos começar a entender porque elas não compartilham da nostalgia pela cultura "tradicional" sentida pela maioria dos viajantes e antropólogos que têm visitado o Baixo Urubamba (Cf. Matthiessen 1962: 211; Huxley \& Capa 1965: 164-7; Ribeiro \& Wise 1978; d'Ans 1982: 263). Os forasteiros são repelidos pelas roupas ocidentais, pelos telhados de zinco 
das casas e pelas embaraçosas perguntas sobre quanto eles ganham e sobre o valor de suas bagagens. Onde estavam as cerâmicas pintadas, as roupas exóticas e as revelaçóes autênticas sobre uma cultura misteriosa escondida? "Porque vir de tão longe para estudar isso?”, é a reação comum, como de fato foi a minha própria. Os Piro parecem ter jogado fora sua cultura, sua preciosa herança da diferença, para alcançarem a identidade sem valor do campesinato pobre.

Assim os Piro como outros povos do Baixo Urubamba não pensam sua cultura como uma posse a ser herdada ou esbanjada. A habilidade para falar piro, fazer cerâmica policromada ou cantar como "os antigos" é conhecimento adquirido. Tal conhecimento é adquirido na relação entre parentes e corresponde aos contextos de tais relaçóes. Se os pais temem que uma inabilidade em falar espanhol conduzirá à escravidão dos seus filhos, então eles encorajam-nos a aprender o espanhol. O conhecimento é importante à medida que protege o andamento dos processos do parentesco e é supérfluo e perigoso se náo o fizer. As pessoas nativas do Baixo Urubamba não vêem suas culturas ancestrais como bens herdáveis, mas como armas em defesa do parentesco. Em momentos particulares tais armas podem ser inúteis e ficarem abandonadas, para serem retomadas depois quando as circunstâncias mudarem. Isto explica porque as pessoas nativas não compartilham conosco a nostalgia pela "cultura autêntica" que nós atribuímos a seus ancestrais. Os "antigos" produziram as pessoas atuais, mas eles estão agora mortos e não podem ajudá-los. São os vivos que devem ser defendidos, com o que está à mão. As pessoas nativas temem a perda de seus filhos, não de sua "cultura"14.

14. Em 1988 fui informado por um jovem em Sepahua que os Piro estavam perdendo sua cultura, esquecendo os hábitos antigos. Disse ele: "As jovens estão envergonhadas de fazerem o ritual da puberdade, porque elas não gostam mais de mostrar seus seios. Mas este é nosso costume e elas não deveriam se envergonhar".
Se considerarmos seriamente o que as pessoas nativas do Baixo Urubamba dizem sobre si mesmas, vemos uma nova dimensão para a cultura descrita nessa etnografia. A cultura das pessoas nativas é sua prática política, seu engajamento concreto com a história. A história narrada pelas pessoas nativas é a história do parentesco. Ela está muito distante de ser simplesmente a narrativa das vítimas do colonialismo e da exploração e é muito diferente de nossa visão externa sobre a história do Baixo Urubamba. A fim de explicar estas diferenças, não podemos recorrer à "cultura tradicional". Por exemplo, seria duplamente absurdo e redutor argumentar que a distância entre nosso entendimento das escolas e aquele das pessoas nativas resulta da mediação deste último através de sua "cultura tradicional". Historicamente, a importância das escolas deve derivar de paradigmas anteriores de conhecimento e poder na cultura nativa (cf. Gow, 1990), mas entre as pessoas nativas contemporâneas a escola aparece de forma proeminente em seu entendimento de conhecimento e poder. Seria um absurdo ver a escola como algo fora do entendimento das pessoas nativas sobre tais coisas e assim separar na análise etnográfica o que na prática dessas pessoas está junto. Também seria extremamente redutor que de algum modo as pessoas nativas desconheçam o que as escolas "realmente são". Sem dúvida, as pessoas nativas náo sabem o que as escolas significam para os funcionários do Estado peruano, para os missionários dominicanos ou para os antropólogos românticos, mas isto náo é a mesma coisa. Como estrangeiros, podemos entender muito bem como as pessoas de kinkon construíram

Este homem não me conhecia e estava muito bêbado quando me contou isso, então suspeitei que ele estava repetindo o que havia ouvido de algum antropólogo ou missionário. Sua declaração não é menos interessante por isso e pode sinalizar uma nova fase de resistência. 
sua escola, mas não temos o direito de dizer que elas o fizeram por um engano. Devemos repensar nossos próprios significados como buscamos enfrentar aqueles das pessoas nativas do Baixo Urubamba.

$\mathrm{O}$ mesmo se aplica ao entendimento que essas pessoas produzem sobre Comunidad $\mathrm{Na}$ tiva. Barclay e Santos (1985) discutiram de forma eloqüente as falhas da lei que instituiu a Comunidad Nativa e argumentaram que essa era uma forma de etnocídio ideológico, atuando para legalizar o roubo da terra das pessoas nativas e destruir sua organização política. Localizando o uso e o direito de posse sobre a terra na comunidade local, a lei das Comunidades Nativas pode ser uma má lei, mas é a única correntemente disponível para eles e devemos explorar como e porque eles a tem usado. No caso do Baixo Urubamba, as pessoas nativas têm situado a Comunidad Nativa no coração de sua organização comunitária e no centro de sua narrativa histórica. Eles têm rejeitado o espírito desta lei, que foi planejada para dar reconhecimento legal a uma ordem "tradicional" pré-existente. Ao invés disso, as pessoas nativas têm dado à Comunidad Nativa um significado progressivo dentro do processo contínuo de produção e defesa do parentesco. Tal reconstrução indígena da Comunidad Nativa de forma alguma exclui uma receptividade à nova e melhor proteção legal às terras das pessoas nativas, como o previsto por Barclay e Santos, e parece estimulá-la ativamente.

A etnografia apresentada neste livro revela um povo nativo amazônico com uma profunda consciência histórica situada nas relaçóes de parentesco. O parentesco para elas não é concebido como uma estrutura atemporal na qual as novas geraçóes são socializadas, mas como um conjunto de relaçóes entre pessoas vivas que são ativamente produzidas no tempo. É difícil saber se as pessoas nativas do Baixo Urubamba são exceçóes entre os povos nativos amazônicos nessa identificação do parentesco e história, já que poucos etnógrafos têm discutido história e parentesco em termos comparáveis àqueles que utilizo aqui.

Tal procedimento é esperado em etnografias dos povos "aculturados", com o foco na incoerência das práticas sociais de seus atores. Mas isto também persegue as etnografias dos povos "tradicionais". Estes estudos constroem uma visão de uma cultura tradicional com uma estrutura particular. Buscando descrever os povos nativos amazônicos, cuja história é desconhecida e fragilmente entendida, os etnógrafos tendem a subestimar o "como se" de suas explicações (Leach 1954). Mesmo quando as etnografias interessam-se pelos processos temporais, tais como casamentos, iniciaçóes ou rituais funerários esses processos são nivelados a fim de mostrar uma estrutura cultural abstrata e atemporal. Não há nada de errado nisso enquanto uma metodologia etnográfica é consensualmente preferível ao redemoinho do espetáculo histórico de uma abordagem mais antiga, onde os povos nativos americanos encontram-se ao acaso em suas migraçóes e deixaram para trás seus "elementos culturais" distintos (cf. Steward 1946: 59, Steward \& Faron 1959). Mas esta metodologia etnográfica torna-se perniciosa quando está disfarçada de análise histórica.

Turner, em seu comentário em um volume dedicado ao mito e à história na América do Sul indígena, escreveu: "A estrutura da sociedade nativa, significando em particular seus modos de produção social, e a estrutura da situação de contato da qual ela participa, não são variáveis independentes" (1988: 280). Estou de acordo, desde que Turner queira dizer que os povos indígenas são agentes de sua própria história e que os etnógrafos deveriam buscar relacionar o conhecimento etnográfico que eles têm de uma sociedade nativa ao seu conhecimento da história dessa sociedade. Mas não é 
isso exatamente o que ele afirma, já que diz que certas sociedades são mais aptas a suportarem as mudanças na história que outras. Ele argumenta que sociedades como os Kayapó, onde a reprodução social da comunidade é coerentemente guiada pelas instituiçóes coletivas, estão mais aptas à consciência histórica e à resistência cultural que sociedades que carecem de tal integração funcional. Turner cita como exemplo dessas últimas "os Shipibo e as sociedades similares das montanhas e das terras baixas sub-andinas marginais" (1988: 209). Ele escreve:

As sociedades andinas e do Brasil Central (...) com seus complexos sistemas de instituiçóes coletivas estão muito melhor adaptadas à manutenção de uma relação de integração e de interação intensiva com a sociedade ocidental local, ao mesmo tempo em que mantém uma identidade coletiva separada e internamente autônoma, do que as sociedades simples, como os Shipibo, os Aguaruna e os Waurá. Os tipos de situaçóes de contato são aqueles em que as primeiras sociedades estão engajadas combinando interdependência, resistência e manutenção de uma identidade social diferenciada no meio do contato intensivo diferem das últimas, com sua ênfase na insulação, distância e contato esporádico (1988: 280).

História é, pois, o desvelamento dentro da "situação de contato", das possibilidades imanentes na estrutura "tradicional" da sociedade nativa. Não considero convincentes as similaridades entre organização das comunidades campesinas andinas e os Kayapó e Bororo. Apesar da presença das instituiçóes comunais dualistas em ambos os casos, a experiência histórica e organização social dos Kayapó ou Bororo têm pouco em comum com aquelas comunidades campesinas andinas que por muitos séculos vêm sendo integradas em complexos sistemas nacionais. Entretanto, simplesmente não con- sigo compreender a caracterizaçáo de Turner da situação de contato dos Aguaruna e Shipibo. Os Aguarauna são famosos, ao menos no Peru, pela força de suas federações políticas e pela reação agressiva a qualquer sinal de ameaça contra sua autonomia, como foi testemunhado durante a campanha contra a tentativa de Werner Herzog de filmar Fitzcarraldo em seu território. Os Shipibo são talvez menos famosos pelo seu ativismo político, mas suas próprias federaçôes e a grande cooperativa shipibo de artesãos, Maroti Shobo, não poderiam rigorosamente ser descritas como "insulares" e nem mesmo o grande número de pessoas Shipibo morando dentro e ao redor da cidade de Pucallpa corroboram a idéia de um "contato esporádico" ${ }^{15}$.

A análise de Turner e sua maneira de classificar essas pessoas como "de montanha e de terras baixas marginais sub-andinas", retoma o Handbook of South American Indians (Steward 1946: 59), onde as culturas da Amazônia Ocidental são englobadas em uma única categoria, já que pouco se sabia a respeito delas, e esse parco conhecimento não apresentava qualquer padrão coerente. Como notou Myers (1974), a classificação para as organizaçôes sociais na Amazônia Ocidental no Handbook era totalmente inadequada e ignorava as complexas mudanças que ocorreram na história. Nosso conhecimento sobre os povos da Amazônia Ocidental está evoluindo, ainda que permaneça inadequado. Ao menos o presente estudo abriu para a possibilidade dos arranjos sociais aparentemente amorfos de povos como os $\mathrm{Ca}$ nelos Quéchua, Shipibo-Conibo, Cocamillia e das pessoas nativas do Baixo Urubamba não serem, em nenhum sentido, "simples", devendo ser estudados no contexto de suas interaçóes

15. A fonte de Turner para os Shipibo é Roe (1988), que fornece a impressão de que eles são "isolados". Suponho que Roe quer dizer que eles são isolados em comparaçáo aos Cocama, em vez de isolados como os Waurá do Alto Xingu (Cf. Ireland 1988). 
com contextos regionais mais amplos. Tal problema fica talvez mais evidente com os Campa, cujas interações com os outros vão do isolamento extremo no vale de Ene e Gran Pajonal à co-residência próxima no Baixo Urubamba e no Ucayali, mas sem revelar quaisquer diferenças significativas em seu modo de reprodução social fora da própria "situação de contato" em si (Bodley 1970). Além disso, a "situação de contato" dos diferentes grupos Campa variou consideravelmente ao longo dos últimos quatro séculos, da missionarização à rebelião, do trabalho para os patrones à guerra. Tais variaçóes espacial e temporal na interação com os sistemas de poder colonial e nacional são comuns em toda Amazônia ocidental e para explicá-la devemos lidar com toda a complexidade histórica dessa região.

Os modismos antropológicos mudam e o "marginal" pode rapidamente tornar-se o "caso típico", como foi claramente demonstrado com a retomada dos estudos dos Jê. Como o próprio Turner acentuou (1988: 237-238), a reflexão sobre a história amazônica deve incluir uma reflexão sobre a história da antropologia e sobre o empreendimento etnográfico. Este ponto foi tratado por Viveiros de Castro em seu estudo sobre os Araweté (1986), onde ele explora a complexa interação entre agenda de mudanças teóricas na antropologia e a atenção voltada às culturas amazônicas particulares e aos problemas que elas propóem. Estudos dos anos 30 e 40 sobre os Tupi-Guarani, influenciadas por escolas americanas e alemãs do culturalismo ou do difusionismo, focaram a fragilidade dessas culturas que caminhavam para a aculturaçáo ou a extinção. Como o estrutural funcionalismo britânico e o estruturalismo francês tornaram-se mais proeminentes, os Tupi-Guarani foram abandonados e a atenção teórica voltou-se para os Jê, que deixaram a sua posição "marginal" para tornar-se "clássicos” (1986: 97).
Esta reflexão sobre a história do projeto antropológico tem implicaçóes importantes para reflexóes antropológicas sobre a história amazônica. Viveiros de Castro sugere que a resistência cultural dos povos Jê, mediada pela organização introspectiva da aldeia, pode ser simplesmente mais visível de uma particular persuasão teórica aos antropólogos do que a resistência dos Araweté e outras culturas Tupi-Guarani, haja vista que elas estão em busca de relaçóes exteriores. Tais culturas, devido às interaçóes que elas buscam com estrangeiros, são fáceis de serem interpretadas em termos de "má fé" ou "vendo eles mesmos com os olhos do mestre", mas somente quando permanecemos cegos para suas próprias dinâmicas culturais (1986: 76). A resistência cultural não pode simplesmente ser "vista" como qualquer outro aspecto da cultura. Ela tem que ser investigada etnograficamente. Que a resistência cultural dos Araweté ou dos povos nativos do Baixo Urubamba não está articulada pelas instituições coletivas não é mais surpreendente que a ausência de aldeias circulares entre eles e nem mais significativo.

Viveiros de Castro indicou a possibilidade de uma história real da Amazônia. Tal história deve considerar eventos enquanto a conjunção de projetos históricos de sociedades indígenas e coloniais. $\mathrm{O}$ expansionismo e a "vontade de dominação" das sociedades nacionais são reais o suficiente, mas são igualmente reais a busca pelo outro do Tupi-Guarani, as aldeias circulares dos Jê-Bororo e o desejo pelo conhecimento externo das pessoas nativas do Baixo Urubamba. Todos eles são realidades históricas e projetos históricos. Tal visão de história amazônica se livraria de categorias como as de sociedades indígenas amazônicas "tradicionais" e "aculturadas". Esses dois tipos de sociedades náo diferem porque um tem uma cultura coerente, mas náo história, enquanto o outro possui história, mas sua cultura é incoerente. Eles diferem apenas nos detalhes de suas culturas e suas histórias. Tal história permite que 
tracemos as múltiplas e complexas estratégias da resistência cultural na Amazônia nativa que Turner ignora, ao mesmo tempo nos aproxima da reflexão sobre o projeto antropológico que Turner tâo corretamente defende.

Para escrever tal história da Amazônia, devemos primeiro nos dar conta que sabemos de fato muito pouco sobre a história da Amazônia. Nessa discussão sobre a historiografia da Amazônia peruana, Santos Granero (1988) observa que esta história tem sido largamente escrita por missionários e antropólogos e que muito pouco foi escrito por historiadores profissionais. Os missionários focaram a história da evangelização, enquanto a produçáo dos antropólogos incide sobre o período mais antigo do "primeiro contato" com os europeus ou sobre as histórias individuais dos povos nativos da Amazônia. Há poucos estudos regionais e menos ainda sobre o desenvolvimento da habilitación, das cidades, da burguesia urbana e do proletariado, ou dos ribereños, o campesinato náo-tribal (Santos Granero 1988). Afirmação semelhante pode ser feita sobre o Brasil, Equador, Colômbia e Bolívia. Estamos, portanto, na posição singular de muitas vezes saber com algum nível de detalhe as reações dos povos indígenas em relação a mudanças históricas, mas náo de compreender por que estas mudanças aconteceram.

Tal problema recaiu sobre este trabalho e conduziu-me eventualmente a abandonar qualquer esforço sério de relacionar a análise da narração das pessoas nativas sobre o passado com a documentação histórica acerca da região. Um bom exemplo desse problema é a figura de Francisco Vargas. Este homem sempre aparece na narraçáo nativa da história, mas quando tentei localizá-lo e identificar suas relaçóes com seus trabalhadores no contexto histórico, defronteime com a falta de documentação e análise. Pouco se sabe sobre as relaçóes sociais da indústria de borracha e menos ainda sobre as décadas que se seguiram. Vargas, meus informantes me dis- seram, chamava os grandes barcos que iam rio acima trazendo mercadorias e mandava os produtos de suas haciendas. Mas para onde e para quem? Com que se parecia o sistema regional que apoiava Vargas? Como isso emergiu da indústria da borracha para se transformar na cena atual? Por alguma ironia cruel, sabemos mais das relaçóes sociais das missóes franciscanas entre os Campa nos primeiros anos do século XVIII do que sobre um sistema social que ainda se mantém vivo na memória das pessoas.

Alguns autores têm dado atenção a esse período pós-colapso da indústria da borracha (Stocks 1984; San Roman 1975), momento que parece ter sido crucial para a formação e consolidação das culturas rural e urbana. Stocks argumenta que tal época viu o desenvolvimento da sociedade rural da Amazônia ribeirinha, com o surgimento das escolas e de pequenas vilas como centros administrativos e isso foi associado às relaçóes de obrigação entre chefes e trabalhadores nativos. Mas praticamente não existem estudos detalhados de tais relaçóes sociais com a notável exceção do próprio trabalho de Stocks (1984) entre os Cocamilla e o de Rummenhoeller (1988) em uma comunidade Shipibo em Madre de Deus.

Pouco surpreende que saibamos táo pouco da história do sistema social ribeirinho da Amazônia ocidental. A história da Amazônia tem sido largamente escrita por antropólogos que demonstraram pouco interesse nas pessoas que não são, em algum sentido óbvio, indígenas. Poucos antropólogos têm trabalhado em cidades da Amazônia peruana ${ }^{16}$, em cidades

16. A pesquisa antropológica em centros urbanos na Amazônia peruana tem sido largamente focada na cura xamânica (cf. Luna 1986 e De Rios 1972). O tema da cura xamânica urbana nessas regióes mostra um número de problemas históricos fascinantes, principalmente à luz do estudo de Taussig (1987) no Sudoeste da Colônia. Abordarei este assunto posteriormente em Gow (s/d). 
menores ou vilas ao longo dos maiores rios da regiáo. A etnografia da Amazônia se manteve cega a tais situaçôes, porque elas não podem facilmente ser encaixadas dentro da visão antropológica para a história da regiáo. Por não serem obviamente indígenas, as pessoas são assimiladas a categorias sociais abstratas, como "sociedade nacional", e suas especificidades culturais são ignoradas.

Em meu trabalho sobre o Baixo Urubamba estava claro para mim que muitos aspectos do sistema local deveriam ser generalizáveis para a Amazônia peruana. As relaçóes de habilitacion com suas imagens correlatas de classe e "raça", certamente são gerais nesta regiáo, como a imagem espacial da cidade, do rio e da floresta. Igualmente a facilidade com que os homens de Pucallpa ou do Ucayalli mais baixo participavam das relaçóes de afinidade dos povos nativos locais sugere uma familiaridade anterior com tais padróes. O idioma do "sangue misturado" era criterioso aqui. Tais homens definiriam a si mesmos como mestizos e freqüentemente evocariam sua própria ascendência como vindo de casamentos entre mulheres nativas amazônicas e homens imigrantes. Suas relaçóes com suas esposas nativas a afins eram, portanto, ligadas por eles a suas próprias identidades pessoais e suas açóes atuais ligadas em uma história de tais ações.

Entretanto, é quase impossível saber se o termo mestizo tem essa profundidade de significados em outras partes da Amazônia peruana. A maioria dos autores utiliza o termo como se ele descrevesse algum grupo de pessoas coerente e definido, separado dos indígenas (Chaumeil 1983, 1984; d'Ans 1982; Luna 1986 ou Siskind 1973). Entretanto, não existem análises sobre o significado do termo para as pessoas que o utilizam para descreverem a si mesmas. Mesmo Chevalier (1982), um dos raros etnólogos a descrever em detalhe as relaçóes sociais de uma pequena cidade ribeirinha (Puerto Inca, no Pachitea), utiliza o termo mestizo sem referência aos discursos locais. Sua falha ao explorar os significados deste termo é o mais notável dado sua descrição detalhada das relaçóes de parentesco e a importância das imagens de espaço e do lugar de origem para o simbolismo de classe. Chevalier concentra-se em uma comparação abstrata entre o sistema local de Puerto Inca e o dos Campa, tal qual foi apresentado por etnólogos como Bodley (1970) e Weiss. Entretanto, ele não fornece informações a respeito das relaçóes concretas entre as pessoas em Puerto Inca e os Campa, e muito pouco sobre como os primeiros falam atualmente dos últimos. A área mais baixa da Pachitea parece similar ao Baixo Urubamba e suspeito fortemente que a ideologia de "raças" e das "pessoas misturadas" deve ser tão penetrante no primeiro caso quanto no último.

Deve ser também interessante comparar as comunidades nativas do Baixo Urubamba com as atuais comunidades ribereño de Ucayali, mas dispomos de pouca informaçáo para a tarefa. Padoch, em sua descriçáo da ecologia do campesinato ribeirinho do Baixo Ucayali, fornece uma pequena amostra das possibilidades. Descrevendo a formação de uma aldeia de trabalhadores errantes ligados a um chefe, ele escreve:

A nova comunidade foi composta por pessoas de diversas origens. Havia ex-Ashaninkas, ex-Cocamas, mestiços que descendiam de unióes entre Cocamas e europeus... Ex-Quechuas que juntaram-se ao grupo no Napo superior, várias mulheres ex-Yagua da malfadada fazenda na Amazônia. Todos consideravam-se ribeirinhos. (1988: 132)

Padoch não fornece o contexto para essas identificaçóes e eu nunca ouvi alguém na Amazônia peruana utilizando termos que poderiam corresponder a "ex-Ashaninka" ou "ex-Cocama”. A heterogeneidade dessa comunidade é similar a das comunidades no Baixo Urubamba 
e deveria ser intrigante saber mais sobre as relaçóes sociais que a estrutura. Suspeito que essas comunidades não são baseadas no princípio do parentesco englobante como o encontrado no Baixo Urubamba, mas está claro na explicação de Padoch que as declaraçóes de descendência dos ancestrais nativos são importantes na definição da identidade. É de importância particular para qualquer análise dessas comunidades uma explicação sobre o que significa ser Cocama na Amazônia peruana contemporânea. Os Cocama são uma grande, porém vaga, população ao longo dos rios Ucayali, Marañon e Amazonas, mas até agora têm atraído pouca atenção ${ }^{17}$.

Um dos aspectos mais surpreendentes sobre a vila descrita por Padoch é que uma comunidade dessas possa se formar e durar sobre fundaçóes aparentemente tão heterogêneas. Não há raízes na "tradição" e as pessoas que residiam nas vilas se liberavam do chefe que originalmente as trouxera juntas. Mas esta comunidade faz claramente sentido para aquelas pessoas e a explicação que Padoch sugere é que ela seja organizada de uma maneira similar a das comunidades nativas do Baixo Urubamba, guardadas certas diferenças. Neste caso, a descendência dos ancestrais Piro e Campa forma o coraçáo do parentesco e fornece o cenário de conexôes dominantes na construção da comunidade enquanto parentes interconectados. Isto é improvável no exemplo fornecido por Padoch. Entretanto, os povos nativos da Amazônia peruana têm outros idiomas para pensar a comunidade enquanto parentesco, como o compadrazgo (compadrio) ${ }^{18}$. Padoch não nos fornece nenhuma explicaçáo para a na-

17. Lathrap (1970) e Roe (1988) também utilizam o termo "ex-Cocama” e não especificam seus equivalentes locais.

18. Mauricio Fasabi uma vez descreveu a Comunidade de Santa Clara como tendo seu início em relaçóes de compadrazgo e só mais tarde desenvolveu, através dos casamentos de suas filhas, em "todos os parentes". Transformações topológicas podem percorrer ambos os caminhos ao menos para certas pessoas. tureza das relaçóes sociais na comunidade que descreveu e nem dispomos de outras pesquisas sobre isso.

Até a elaboração desses estudos, minha explicação para a organização social do Baixo Urubamba permaneceu problemática. Lendo Padoch, presumo fortemente que as comunidades ribeirinhas do Ucayali e Amazônia são transformações topológicas das comunidades nativas que estudei. Um pequeno redirecionamento do foco nos idiomas das comunidades, menos ênfase na ascendência comum e nos laços englobantes entre parentes e mais no compadrazgo - conduziria de uma a outra. Essas pequenas mudanças teriam profundos efeitos nas formas atuais das comunidades, particularmente com referência à circulação da caça e ao peso empregado na identidade pessoal em termos de "tipos de gente". Na verdade, o único significado que posso pensar para termos como "ex-Ashaninka" ou "ex-Cocama" é na situação onde "tipos de pessoas" sáo dispostos na geração dos pais ou superior: onde "tipos de pessoas" operam como identidade nas geraçóes ascendentes, mas isso não funciona como uma identidade pessoal para pessoas no presente. Essas especulaçóes, e elas devem permanecer como tal até que pesquisas confirmem ou rejeitem-nas, sugerem um novo cenário de possibilidades para interpretar a história amazônica. Argumentei anteriormente que a organização social das pessoas nativas do Baixo Urubamba era uma transformação topológica das organizaçóes das comunidades "tradicionais" da Amazônia. Sugeri também que as interelaçóes dessas comunidades com os sistemas regionais mais amplos são possíveis porque as pessoas na Amazônia reconhecem sistemas transformacionais e agem sobre eles. Esta parece ser a única maneira pela qual podemos explicar a facilidade relativa pela a qual as pessoas nativas no Baixo Urubamba podem mudar para grandes cidades como Pucallpa, pela qual os homens mestizos 
podem se mover para as comunidades nativas, pela qual um cenário de pessoas aparentemente aleatório pode criar a comunidade descrita por Padoch. Estou sugerindo que todas essas populaçóes heterogêneas da Amazônia ocidental se compreendem umas as outras, e é tarefa da antropologia descobrir porque isso ocorre.

Como essa compreensão é possível? Não pode ser porque eles sáo todos "tradicionalmente" o mesmo ou similares, porque incluem modos de existência social que não tinham precedência na cultura pré-colombiana, como grandes cidades e as haciendas. $\mathrm{O}$ sistema sócio-econômico da Amazônia ocidental é produto da inserção do capitalismo e está conectado aos mercados mundiais. Mas este sistema de transformação não pode ser explicado mediante a inserção do capitalismo destruindo toda a variaçáo local e a recolocando com o simples discurso "moderno" sobre a vida social, pois inclui grupos indígenas que têm pouco ou mesmo nenhum contato com o "mundo moderno". A prática atual das transformaçóes topológicas da vida social da Amazônia Ocidental é apenas possível sob duas condiçóes: que ela seja historicamente desenvolvida; e que as pessoas nativas da Amazônia sejam os agentes centrais dessa evoluçáo histórica. Certamente não lhes faltou tempo para construírem esse sistema de transformaçóes das possibilidades já existentes. Em 1542 Orellana descobriu a Amazônia e as pessoas da Amazônia descobriram a Europa.

Uma análise completa desse complexo sistema escapa ao escopo desse trabalho e, como tenho dito, muita pesquisa histórica e etnográfica ainda está por ser feita. Neste estudo limitei-me à etnografia de um pequeno número de pessoas em poucas comunidades ao longo de um rio amazônico. Buscando a solução para o problema colocado pela sua aparente "aculturação", fui conduzido para uma análise de suas próprias narrativas sobre o passado. Essa investigação revelou para mim essas pessoas enquanto agentes históricos ativos, com uma profunda consciência de seu passado, seu presente e suas possibilidades para o futuro. Conforme me movia da história das pessoas nativas do baixo Urubamba para uma análise do parentesco e daí para a história para as pessoas nativas do Baixo Urubamba, fui conduzido a um problema central: nossa ignorância sobre o que aconteceu no passado da Amazônia. Essa ignorância é real, e até que algo seja feito a respeito, náo podemos entender como antropólogos a agência histórica das pessoas nativas da Amazônia.

Não há nada particularmente inusitado em minha abordagem, desde que isso foi explorado com infinita densidade por Lévi-Strauss, que ainda é ritualmente castigado por ignorar a história (cf. Hill 1988). O que, então, fazemos de Tristes Trópicos? Meditando sobre sua jornada pelo Brasil Central, Lévi-Strauss questiona insistentemente sobre em que condiçôes nós podemos conhecer o passado e qual é a relevância de tal conhecimento ${ }^{19}$. História e etnografia se confrontam continuamente nesse texto. Discutindo sua visita aos Mundé, ele argumenta que a falta de tempo e recursos para um estudo etnográfico apropriado torna sua experiência entre esses pristine savage sem sentido. Como Lévi-Strauss não dominava a língua, os Mundé permanecem um enigma para o antropólogo. Essa experiência enigmática confirma a rejeição de Lévi-Strauss da prioridade da história:

19. A importância da análise histórica no trabalho de Lévi-Strauss tem sido quase despercebida. Tristes Trópicos é ou ignorado ou mal lido por aqueles que comentam a discussão de Lévi-Strauss sobre o tempo, por exemplo, Fabian (1983). Uma exceção é Maurice Bloch, que anunciou em um seminário no London School of Economics que Tristes Trópicos é um livro obcecado com a história (Bloch 1986). 
Dentro de poucos séculos, nesse mesmo lugar, outro viajante táo desesperado quanto eu vai lastimar o desaparecimento do que eu poderia ter visto, mas fracassei em ver (1973: 51).

Portanto, para Lévi-Strauss, o problema central da história se refere às condiçôes sobre as quais nós podemos conhecê-la. E porque não podemos vislumbrar o que aconteceu na história amazônica, somos forçados a enfrentar as dolorosas tarefas da análise de evidências documentais e da investigação etnográfica. Como ato de aprender uma língua desconhecida, tal tarefa implica em aceitar as profundidades da nossa ignorância, ao mesmo tempo estender ao máximo nosso limitado conhecimento.

Minha análise seguiu um dos pólos do projeto de Lévi-Strauss, tendo em vista que me preocupei com a etnografia mais do que com a história. Considerando seriamente o que as pessoas nativas do Baixo Urubamba dizem sobre o passado, deixei de lado em grande parte o problema da evidência histórica. Entretanto, através do trabalho etnográfico, habilitei-me a levantar importantes questóes sobre esta história cujas respostas somente podem ser fornecidas pelas análises históricas. Não menos importante entre essas é a agência histórica das pessoas nativas amazônicas. Como Lévi-Strauss anunciou há algum tempo:

"O sociólogo, enquanto isso, deve sempre ter em mente que as instituiçôes primitivas não são somente capazes de preservar o que existe, ou de guardar brevemente um passado despedaçado, mas também de elaborar audaciosas inovaçóes mesmo que as estruturas tradicionais sejam profundamente transformadas”. ([1942]1976: 339)

Já conhecemos bastante sobre as profundas transformações nas estruturas tradicionais nativas da Amazônia. Esse estudo investigou uma de suas inovaçôes audaciosas.

\section{Referências bibliográficas}

ALVAREZ, Ricardo. 1957. “¿Piros en el Urubamba?”. Missiones dominicanas, 38: 263-5.

1970. Los Piros: Hijos de dioses. Lima: Heraclio Fournier SA.

ARHEM, Kaj. 1981. Makuna Social Organization: A Study in Descent, Alliance and the Formation of Corporate Groups in North-West Amazon. Uppsala Studies in Cultural Anthropology 4, Uppsala.

BALDUS, Herbert. 1964. "O xamanismo na aculturação de uma tribo tupi do Brasil Central", Revista do Museu Paulista, 15: 319-27.

BARCLAY, Frederica; SANTOS, Fernando. 1985. "Las Comunidades nativas: Un etnocidio ideológico". Amazonia Indígena, 9: 3-4.

BARTH, Fredrik. 1969. (ed.), Ethnic Groups and Boundaries: the social organization of cultural difference. Boston: Little, Brown.

BIDOU, Patrice. 1972. "Représentations de l'espace dans la mythologie tatuyo (Indiens Tucano". Journal de la Societé das Americanistes, 61: 45-108.

1977. "Nâitre et être tatuyo". In J. Kaplan (ed.), Social Time and Social Space in Lowland South American Societies: Actes du XLII Congrès International des Américanistes II, Paris.

BODLEY, John H. 1970. 'Campa Socio-economic Adaptation' (manuscript), Ann Arbor, Mich.

BLOCH, Maurice. 1986. From Blessing to Violence: History and Ideology in the Circumcision Ritual of the Merina of Madagascar.Cambrigde: Cambrigde University Press.

BLU, Karen. 1980. The Lumbee Problem: The Making of an American Indian People. Cambridge: Cambridge University Press.

CARDOSO DE OLIVEIRA, Roberto. 1972. O indio e o mundo dos broncos: Uma interpretação sociológica da situação dos Tukuna. São Paulo: Livraria Pioneira Editora.

CARRIER, James G. 1987. "History and Self-Conception in Ponam Society". Man, 22: 111-31.

CASEVITZ, France-Marie. 1977. "Du proche au loin: Étude du fontionnement des systèmes dela parenté et de l'alliance matsiguenga". In J. Kaplan (ed.), Social Time and Social Space in Lowland South American Societies: Actes du XLII Congrès International des Américanistes II, Paris.

CHAUMEIL, Jean-Pierre. 1983. Voir, savoir, pouvoir: Le Chamanisme chez les Yagua du nord-est du Pérou. Paris : Éditions de l'École des Hautes Études en Science Sociales. 
1984. Between Zoo and Slavery: The Yagua of Eastern Peru in their Present Situation. Copenhagen: IWGIA.

CHEVALIER, Jacques M. 1982. Civilization and the Stolen Gift: Capital, Kin and Cult in Eastern Peru. Toronto: University of Toronto Press.

CHIRIF, Alberto; MORA, Carlos. 1977. Atlas de Comunidades nativas. Lima: SINAMOS.

CROCKER, Christopher. 1979. "Selves and Alters among the Eastern Bororo". In Maybury-Lewis (ed.), Dialectical Societies: The Ge and Bororo of Central Brazil. Cambrigde Mass., and London: Harvard University Press.

D’ANS, André-Marcel. 1982. L'Amazonie péruvienne indigène. Paris: Payot.

DE RIOS, Marlene Dobkin. 1972. Visionary Vine: Psychedelic Healing in Peruvian Amazon. San Francisco: Chandler.

FABIAN, Johannes. 1983. Time and the Other: How Anthropology Make its Object, New York: Columbia University Press.

FAULHABER, Priscila. 1987. O navio encantado: Etnia $e$ alianças em Tefé. Belém: Coleção Eduardo Galvão, Museu Paraense Emílio Goeldi.

FERNÁNDEZ, Eduardo. 1986. Para que nuestra historia no se pierda: Testimonios de los Asháninca y Nomatsiguenga sobre la colonización de la región Satipo-Pangoa. Lima: CIPA.

GALVÃO, Eduardo. 1959. "Aculturação indígena no Rio Negro". Boletim do Museu Paraense Emílio Goeldi, 5/1: 67-74

GOW, Peter. 1990. “'Aprendiendo a defenderse': La historia oral y el parentesco en el Bajo Urubamba”. Amazonia Indigena, 11: 10-16.

. (s.d.) "Shamanism and History in Western Amazonia". (manuscrito inédito).

HILL, Jonathan D. 1984. "Social Equality and Ritual Hierarchy: the Arawakan Wakuénai of Venezuela". American Ethnologist, 20(1): 528-44.

1988. Rethinking History and Myth: Indigenous South American Perspectives on the Past, Urbana, Ill. I Chicago: University of Illinois Press.

HUGH-JONES, Christine. 1979. From the Milk River: Spatial and Temporal Processes in Northwest Amazonia. Cambridge: Cambridge University Press.

HUGH-JONES, Stephen. 1979. The Palm and the Pleiades: Initiation and Cosmology in Northwest Amazonia. Cambridge: Cambridge University Press.

HUXLEY, Matthew; CAPA, Cornell. 1965. Farewell to Eden. London: Chatto \& Windus.
IRELAND, Emilienne. 1988. "Cerebral Savage: The Whitemen as Symbol of Cleverness and Savagery in Waurá Myth”. In Hill (ed.), Rethinking History and Myth: Indigenous South American Perspectives on the Past, Urbana, Ill. / Chicago: University of Illinois Press.

KAPLAN, Joanna. 1975. The Piaroa: a people of the Orinoco Basin. Oxford: Oxford University Press.

LATHRAP, Donald W. 1970. The Upper Amazon. Southampton: Thames \& Hudson.

LEACH, Edmund. 1954. The Political Systems of the Highland Burma. London: Bell.

LEA, Vanessa. 1986. Nomes e Nekrets Kayapó: Uma Concepçâo de Riqueza. Tese de doutorado. Rio de Janeiro: Museu Nacional, datilo.

LEHNERTZ, Jay. 1972. "Juan Santos, Primitive Rebel on the Campa Frontier (1742-1752)". Actas del XXXIX Congreso de Americanistas, 4: 111-26.

LÉVI-STRAUSS, Claude. 1942/1976. "Guerra e comércio entre os índios da América do Sul”. In Egon Schaden (org.), Leituras de etnologia brasileira. São Paulo: Editora Nacional.

.1963. "The Concept of Archaism in Anthropology”. In Structural Anthropology II. London: Allen Lane.

1966. The Savage Mind. London: Weidenfeld \& Nicolson.

.1970. Mythologiques I: The Raw and the Cooked. London: Jonathan Cape.

1973. Tristes Tropiques. London: Jonathan Cape. .1977. "The Scope of Anthropology”. In Structural Anthropology II. London: Allen Lane.

.1981. Mythologiques IV: The Naked Man. London: Jonathan Cape.

LOEFFLER, L.G., e BAER, G. 1974. 'The Kinship Terminology of the Piro, Eastern Peru'. Ethnologie Zeitschrift, 1: 257-82.

LUNA, Luis Eduardo. 1986. "Vegetalismo: Shamanism among the Mestizo Population of Peruvian Amazon". Stockholm Studies in Comparative Religion, 27, Stockholm.

MATTESON, Esther. 1955. 'Analysed Piro Text: A Boy and a Jaguar'. Kroeber Anthropological Society Papers, 12: 22-44.

MATTHIESSEN, Peter. 1962. The Cloud Forest: A Chronicle of the South American Wilderness. London: André Deutsch.

MORPHY, Howard; MORPHY, Frances. 1984. "The 'Myths' of Ngalakan History: Ideologies and Images of the Past in Northern Australia”. Man, 19: 459-78. 
MURATORIO, Blanca. 1987. Rucuyaya Alonso y la historia social y económica de Alto Napo 1850-1950. Quito: Ediciones Abya-Yala.

MURPHY, Robert F. 1960. Headhunters' Heritage: Social and Economic Change among the Mundurucú Indians. Berkeley, Calif.: University of California Press.

MYERS, Thomas. 1974. "Spanish Contacts and Social Change on the Ucayali River, Peru". Ethnohistory, 21(2): 135-59.

OVERING KAPLAN, Joanna. 1981. "Review article: Amazonian Anthropology". Journal of Latin American Studies, 13(1): 151-164.

PADOCH, Christine. 1988. "Peoples of the Floodplain and Forest". In Julie Sloan Denslow and Christine Padoch (eds.), People of the Tropical Rain Forest. Berkeley, Calif., and Los Angeles: University of California Press and the Smithsonian Institution.

PRICE, David. 1987. "Nhambiquara Geopolotical Organization". Man ns 22: 1-24.

RIBEIRO, Darcy. 1970. Os indios e a civilizaçâo: A integração das populaçôes indígenas no Brasil moderno. São Paulo: Vozes.

; WISE, Mary Ruth. 1978. Los grupos étnicos de la Amazônia peruana, Lima: ILV.

RIVIÈRE, Peter. 1984. Individual and Society in Guiana: a Comparative study of Amerindian Social Organization. Cambridge: Cambridge University Press.

ROE, Peter. 1988. "The Josho Nahuanbo Are All Wet and Undercooked: Shipibo Views of the Whiteman and the Incas in Myth, Legend and History. In Hill (ed.), Rethinking History and Myth: Indigenous South American Perspectives on the Past, Urbana, Ill., and Chicago: University of Illinois Press.

RUMMENHOELLER, Klaus. 1988. "Los Shipibos en Madre de Dios: La historia no escrita". Perú Indígena, 27: 13-33.

SCAZZACHIO, Françoise. 1979. Ethnicity and Boundary Maintenance among Peruvian Forest Quechua, Ph.D. dissertation, University of Cambridge.

SAN ROMAN, Jesús V. 1975. Perfiles históricos de la Amazonía Peruana. Iquitos: CETA.

SANTOS GRANERO, Fernando. 1988. "Avances y limitaciones de la historiografía amazónica: 1950-1988". In F. Santos (ed.), I Seminario de Investigaciones Sociales en la Amazonía. Iquitos: CETA.

SISKIND, Janet. 1973. To Hunt in the Morning. London, Oxford, and New York: Oxford University Press.

STEWARD, Julien H. 1946. (ed.), Handbook of South American Indians. Washington, DC: Bulletin of the Bureau of American Ethnology.
; FARON, Louis C. 1959. Native Peoples of South America. New York: McGraw Hill.

STOCKS, Anthony W. 1976. "Notas sobre los autóctonos tupí del Perú”. Amazonía Peruana, 1: 59-72.

.1984. "Indian policy in Eastern Peru". In Marianne Schmink and Charles H. Wood (eds.), Frontier Expansion in Amazonia, Gainesville, Fla.: University of Florida Press.

STRATHERN, Marilyn. 1981. Kinship at the Core: An Anthropology of Elmdon, A village in North-West Essex in the Nineteen-Sixties. Cambridge: Cambridge University Press.

TAYLOR, Anne-Christine. 1981. "God-Wealth: the Achuar and the Missions". In Whitten 1981.

TAUSSIG, Michael. 1987. Shamanism, Colonialism and the Wild Man: Healing, Terror and Space of Death. Chicago: University of Chicago Press.

TURNER, Terence. 1979. "The Ge and the Bororo Societes as Dialectical Systems: A General Model". In David Maybury-Lewis (ed.), Dialectical Societies: the Ge and Bororo of Central Brazil. Cambridge, Mass., and London: Harvard University Press.

1988. "Ethno-ethnohistory: Mith and History in Native South American Representations of Contact with Western Society". In J. Hill (ed.), Rethinking History and Myth: Indigenous South American Perspectives on the Past, Urbana, Ill., and Chicago: University of Illinois Press.

VARESE, Stefano. 1972. "Inter-ethnic Relations in the Selva of Peru". In W. Dostal (org). The Situation of the Indians in South American: Contribution to the Study of Inter-ethnic Conflit in the Non-Andian Regions of South America. Geneva: World Council of Churches.

1973. La sal de los cerros (una aproximación al mundo Campa). Lima: Retablo de Papel Ediciones.

VIVEIROS DE CASTRO, Eduardo. 1986. Araweté: Os deuses canibais. São Paulo: ANPOCS.

WAGLEY, Charles e GALVÃO, Eduardo. 1949. The Tenetehara Indians of Central Brazil. New York: Columbia University Press.

WHITTEN, Norman. 1976. Sacha Runa: Ethnicity and Adaptation of Ecuadorian Jungle Quichua. Urbana, III: University of Illinois Press.

1981. Cultural Transformations and Ethnicity in Modern Ecuador. Urbana, Ill.: University of Illinois Press. 1985. Sicuanga Runa: The Other Side of Development in Amazonian Ecuador. Urbana, Ill.: University of Illinois Press.

WOLF, Eric. 1982. Europe and the People without History. Berkeley Calif.: University of California Press. 
$226 \mid$ Peter Gow

traduzido de

GOW, Peter. 1991. Of Mixed Blood: Kinship and History in Peruvian Amazonia.

Oxford Studies in Social and Cultural Anthropology. Oxford: Oxford

University Press. pp. 1-20; 274-298.

tradutor Anna Maria de Castro Andrade

Mestre em Antropologia Social / USP

tradutor Jayne Hunger Collevatti

Doutoranda em Antropologia Social / USP

tradutor Ugo Maia Andrade

Doutor em Antropologia Social / USP

revisor Marta Amoroso

Professora do Departamento de Antropologia / USP

revisor Jessie Sklair

Mestranda em Antropologia Social / USP

Recebido em 08/05/2006

Aceito para publicação em 15/01/2007 